\title{
Evolution of fluid expulsion and concentrated hydrate zones across the southern Hikurangi subduction margin, New Zealand: An analysis from depth migrated seismic data
}

\author{
Andreia Plaza-Faverola \\ GNS Science, Avalon, Lower Hutt 5010, New Zealand (a.plaza@gns.cri.nz)
}

Dirk Klaeschen

GEOMAR, Helmboltz Centre for Ocean Research Kiel, DE-24148 Kiel, Germany

Philip Barnes

NIWA, Wellington 6241, New Zealand

Ingo Pecher

School of Environment, University of Auckland, Auckland 1142, New Zealand

GNS Science, Avalon, Lower Hutt 5010, New Zealand

Stuart Henrys

GNS Science, Avalon, Lower Hutt 5010, New Zealand

\author{
Joshu Mountjoy \\ NIWA, Wellington 6241, Nerw Zealand
}

[1] Identification of methane sources controlling hydrate distribution and concentrations in continental margins remains a major challenge in gas hydrate research. Lack of deep fluid samples and high quality regional scale seismic reflection data may lead to underestimation of the significance of fluid escape from subducting and compacting sediments in the global inventory of methane reaching the hydrate zone, the water column and the atmosphere. The distribution of concentrated hydrate zones in relation to focused fluid flow across the southern Hikurangi subduction margin was investigated using high quality, long offset (10 km streamer), pre-stack depth migrated multichannel seismic data. Analysis of low P wave velocity zones, bright-reverse polarity reflections and dim-amplitude anomalies reveals pathways for gas escape and zones of gas accumulation. The study shows the structural and stratigraphic settings of three main areas of concentrated hydrates: (1) the Opouawe Bank, dominated by focused periodic fluid input along thrust faults sustaining dynamic hydrate concentrations and gas chimneys development; (2) the frontal anticline, with a basal set of protothrusts controlling permeability for fluids from deeply buried and subducted sediments sustaining hydrate concentrations at the crest of the anticline; and (3) the Hikurangi Channel, with buried sand dominated channels hosting significant amounts of gas beneath the base of the hydrate zone. In sand dominated channels gas injection into the hydrate zone favors highly concentrated hydrate accumulations. The evolution of fluid expulsion controlling hydrate formation offshore southern Hikurangi is described in stages during which different methane sources (in situ, buried and thermogenic) have been dominant. 
Components: 11,100 words, 9 figures, 3 tables.

Keywords: Hikurangi margin; concentrated hydrates; depth migrated seismic; methane sources; subduction.

Index Terms: 3004 Marine Geology and Geophysics: Gas and hydrate systems; 3025 Marine Geology and Geophysics: Marine seismics (0935, 7294); 3060 Marine Geology and Geophysics: Subduction zone processes $(1031,3613,8170,8413)$

Received 9 May 2012; Revised 26 July 2012; Accepted 26 July 2012; Published 29 August 2012.

Plaza-Faverola, A., D. Klaeschen, P. Barnes, I. Pecher, S. Henrys, and J. Mountjoy (2012), Evolution of fluid expulsion and concentrated hydrate zones across the southern Hikurangi subduction margin, New Zealand: An analysis from depth migrated seismic data, Geochem. Geophys. Geosyst., 13, Q08018, doi:10.1029/2012GC004228.

\section{Introduction}

[2] Understanding processes of formation and identification of methane accumulations within marine sediments has gained importance due to methane's potential as a global natural gas resource and as a greenhouse gas capable of triggering global warming [e.g., Heimann, 2010]. Methane in the Earth's crust primarily result from organic matter degradation (i.e., microbial or thermogenic) [e.g., Schoell, 1988; Wiese and Kvenvolden, 1993] and to a lesser extent from chemical reduction of $\mathrm{CO}_{2}$ in hydrothermal emissions often referred to as abiogenic methane [e.g., Fiebig et al., 2009]. To assess the role of natural methane emission as climate mediator, sources and mechanisms triggering methane leakage from sedimentary basins needs to be better understood [e.g., Kroeger et al., 2011].

[3] Under particular temperature, pressure and salinity conditions significant amounts of methane can be stored as gas hydrates in marine settings [e.g., Kvenvolden, 1993; Sloan, 1998]. Water column samples and sediment cores of usually less than the top $10 \mathrm{~m}$ of sediments from seafloor seeps, often suggest that the methane seeping from marine gas hydrate fields is dominantly microbial in origin [e.g., Kvenvolden, 1995; Borowski et al., 1997; Greinert et al., 2010]. However, geochemical data from the few places where DSDP/ODP sites [e.g., Abegg et al., 2007] or test wells (e.g., Mount Elbert, Alaska) are available [e.g., Lorenson et al., 2011], show signatures of thermogenic methane and higher hydrocarbons in addition to microbial methane. Moreover, model results indicate that rates of in situ microbial methane generation are not sufficient to explain estimated hydrate saturations within the gas hydrate stability zone (GHSZ) [Paull et al., 1994; Wallmann et al., 2006; Burwicz et al., 2011]. Processes such as methane recycling and migration of fluids toward focused locations within the GHSZ [e.g., Minshull and White, 1989; Holbrook et al.,
1996; Pecher et al., 2001] are essential to sustain the significant gas hydrate accumulations estimated to exist globally [e.g., Kvenvolden, 1988].

[4] Integrated multiresolution seismic studies have shown that seafloor seeps and gas chimneys are often linked to underlying permeable faults and it has been suggested that deep fluid migration through faults partially controls hydrate distribution [e.g., Roberts and Carney, 1997; Berndt, 2005; Pecher et al., 2010]. Hydrate distribution in marine sediments may be homogeneous and stable sustained by low-methane flux like in Blake Ridge [e.g., Gorman et al., 2002] or may be dynamic and changeable controlled by local and periodic high fluid fluxes, usually associated to gas chimneys like in the Nyegga pockmark field offshore Norway [e.g., PlazaFaverola et al., 2011].

[5] Along the Hikurangi subduction margin offshore New Zealand gas hydrates have been collected from the upper few meters of sediments in gravity cores at active methane seeps and widespread hydrate accumulations are inferred from imaged bottom simulating reflectors (BSRs) [Pecher et al., 2010; Crutchley et al., 2011; SO-214 Scientific Party, 2011]. In this study we image a $150 \mathrm{~km}$ long and $15 \mathrm{~km}$ deep transect across the southern Hikurangi margin to identify fluid accumulations and pathways sustaining concentrated hydrate zones across the margin.

[6] We use deep-penetration wide-angle multichannel seismic (MCS) reflection data to identify indicators of gas supply into the GHSZ from deep sediments. The investigated seismic transect extends from $\sim 800 \mathrm{~m}$ water depths, $10 \mathrm{~km}$ SE of Cape Palliser, across active thrust faults beneath Opouawe Bank, to the $\sim 2500 \mathrm{~m}$ deep Hikurangi Trough and Channel, and terminates on the northern Chatham Rise slope (Figure 1a).

[7] Given that the hydrate province lies within highly deformed, accreted sediments characterized 


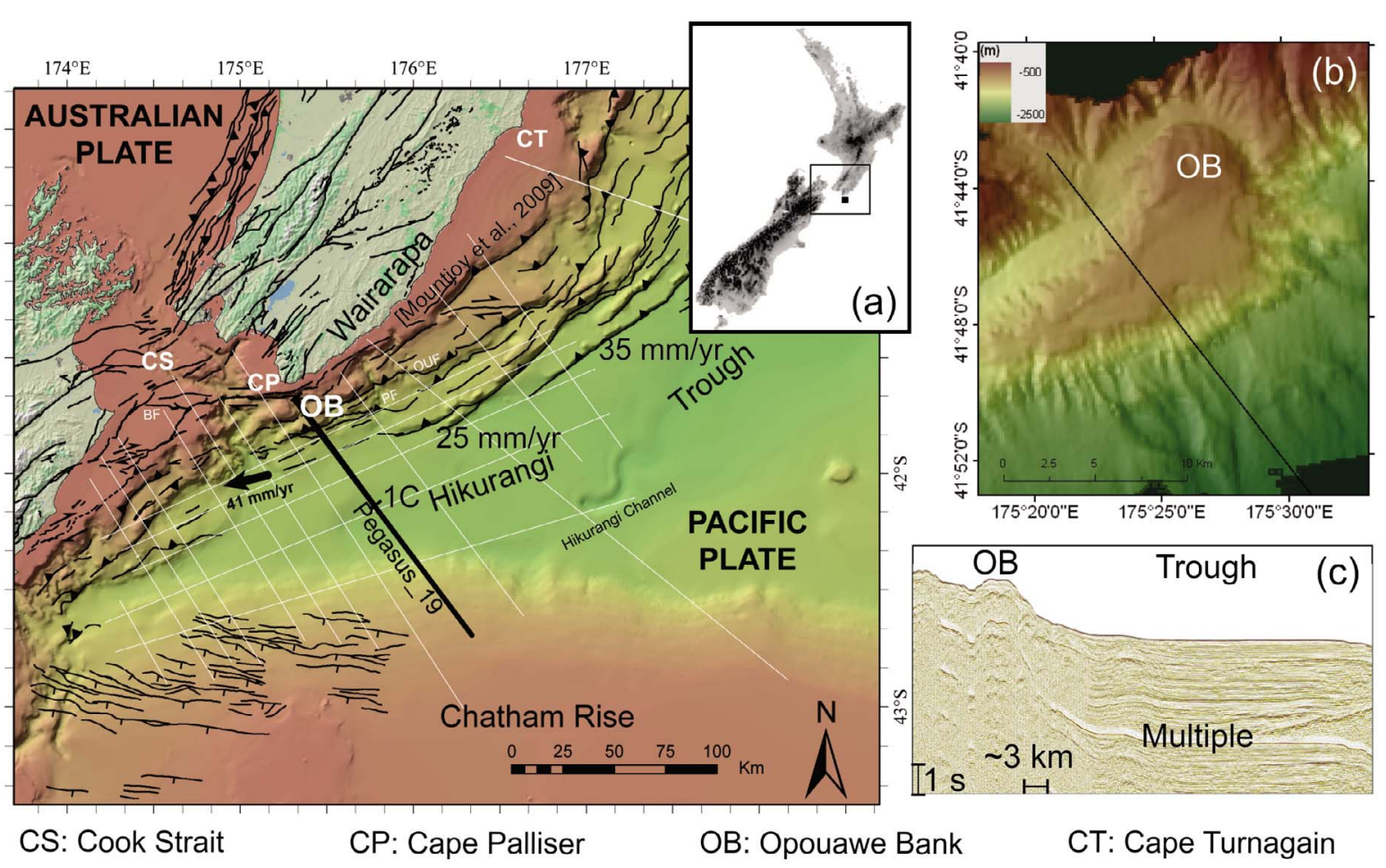

Figure 1. (a) Location map across the southern Hikurangi margin, New Zealand's North Island. Seismic lines from surveys used for stratigraphic correlation are indicated (white lines). Pacific-Australian plate motion rates are from Beavan et al., [2002]; trench convergence rates from Wallace et al., [2012]. Faults from Barnes [1994b], Mountjoy et al. [2009] and Wallace et al. [2012]; (b) closer view of the Opouawe Bank; (c) near trace shot gather (two-way time) along part of Pegasus_19 showing the raw seismic character at Opouawe Bank and Hikurangi Trough.

by complex thrust faults and fluid escape features extending to the subducting plate interface (the basal décollement at $>10 \mathrm{~km}$ depth), conventional common-depth-point (CDP) velocity analysis and migration in the time domain do not provide reliable imaging. We applied an iterative pre-stack depth migration (PSDM) procedure, that uses seismic velocities constrained by focusing analysis and common reflection point gathers. The resulting PSDM and velocity image establish the relationship between deep and shallow fluid regimes, where thrust faults, proto-thrusts and chimney-like features are conduits for fluids from deeply buried and subducted sediments into the hydrate zone and the seafloor. The evolution of fluid flow and hydrate accumulations is described in stages in which mixed microbial and thermogenic methane sources are suggested to have played major roles.

\section{Geological Background}

[8] The Hikurangi margin of eastern North Island, New Zealand, is a sediment-rich active continental margin associated with westward subduction of the Pacific Plate beneath New Zealand's continental crust [Cole and Lewis, 1981]. The subducting Pacific Plate incorporates the 120 Ma Hikurangi Plateau, an oceanic Large Igneous Province that was previously subducted southward beneath the Chatham Rise [e.g., Wood and Davy, 1994; Davy et al., 2008; Reyners et al., 2011]. The current oblique subduction of the plateau beneath North Island is marked by the $2500-3300 \mathrm{~m}$ deep Hikurangi Trough [e.g., Lewis and Pettinga, 1993].

[9] Offshore Wairarapa, where the current investigation is focused, the Hikurangi Trough is approximately $65 \mathrm{~km}$ wide (Figures 1 and 2). Cenozoic sediments terminate abruptly against the accretionary continental slope to the northwest, and lie unconformably over the Hikurangi Plateau and Chatham Rise to the east and southeast, respectively [Lewis et al., 1998]. Seafloor sediment cores $(<5 \mathrm{~m}$ length) indicate that the Hikurangi Trough sediments consist predominantly of alternating clastic turbidites associated with the submarine 

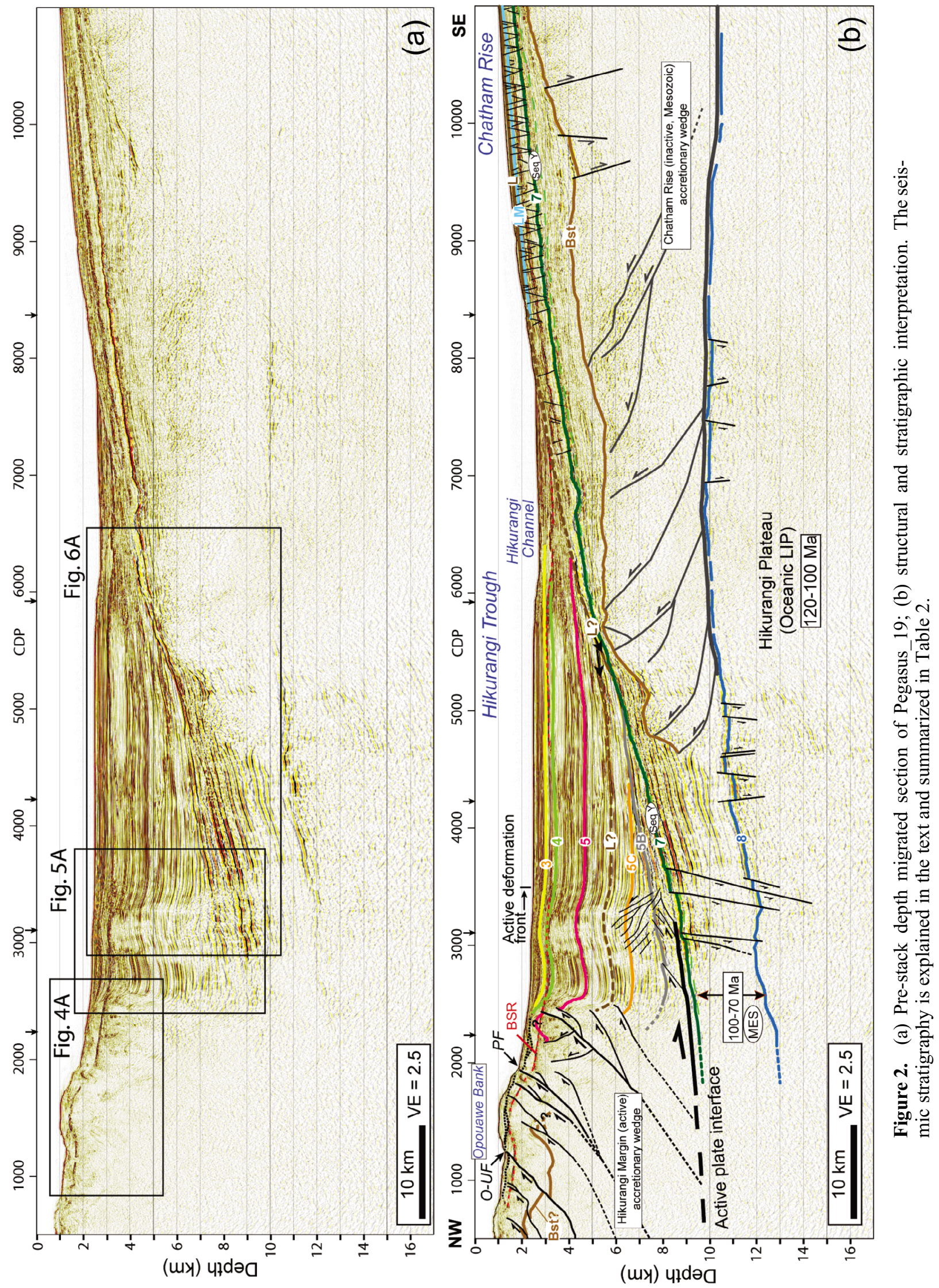
Table 1. Acquisition Parameters and Signal Resolution

\begin{tabular}{ll}
\hline \multicolumn{1}{c}{ Parameter } & Pegasus_19 \\
\hline Profile length $(\mathrm{km})$ & 150 \\
Dominant Frequency (Hz.) & 25 \\
Vertical resolution $\lambda / 4(\mathrm{~m})$ & $\sim 15$ \\
Fresnel zone $(\mathrm{m}) @ \mathrm{sf}$ & $\sim 460$ \\
Sampling interval $(\mathrm{ms})$ & 4 \\
Recording length $(\mathrm{ms})$ & 12000 \\
Streamer length $(\mathrm{km})$ & 10 \\
Minimum nominal offset $(\mathrm{m})$ & 133 \\
Maximum offset $(\mathrm{m})$ & 10120 \\
Active channels & 800 \\
Shot interval $(\mathrm{m})$ & 37.5 \\
Original CDP bin interval $(\mathrm{m})$ & 6.25 \\
Used CDP bin interval $(\mathrm{m})$ & 12.5 \\
\hline
\end{tabular}

Hikurangi channel system, and hemipelagic muds [Lewis and Pantin, 2002].

[10] The continental slope comprises a series of ridges and basins associated with generally seawardverging thrust-faulted anticlines [Davey et al., 1986; Lewis and Pettinga, 1993; Barnes and Mercier de Lépinay, 1997; Barker et al., 2009; Barnes et al., 2010]. The inner margin is underlain by highly imbricated pre-subduction Cretaceous and Paleogene passive margin sedimentary rocks. The outer margin is underlain by the Late Cenozoic accretionary wedge. The outer wedge increases in width from $\sim 15 \mathrm{~km}$ off Cape Palliser to $\sim 70 \mathrm{~km}$ off Cape Turnagain (Figure 1). Rapid frontal accretion, reflected by seaward advance of the deformation front at the widest part of the wedge, is estimated to have occurred during late Quaternary at a rate of up to $100 \mathrm{~m} / \mathrm{kyr}$ [Barnes et al., 1998]. The rate of orthogonal convergence along the southern part of the margin is estimated to decrease southward from about 35 to $25 \mathrm{~mm} / \mathrm{yr}$ (Figure 1) [Wallace et al., 2012]. Local back thrusts and landwardverging anticlines have been interpreted toward the southwestern edge of the accretionary slope off Cook Strait [Barnes et al., 1998; Uruski, 2010].

\section{Seismic Data and Processing}

[11] Wide-angle, deep penetration multichannel seismic data (MCS) were commissioned by New Zealand's Ministry of Economic Development (MED) to promote hydrocarbon exploration. The Pegasus survey collected 26 2D profiles in Pegasus basin in 2009 (Geotrace, Pegasus, Bounty Trough, Great South Basin and Sahke processing report, unpublished petroleum report PR4279, Ministry of Economic Development, Wellington, New Zealand, 2010). This study focuses on line Pegasus_19
(Figure 1) which crosses Opouawe Bank, where active gas seepage has been documented [e.g., Greinert et al., 2010]. The air gun array had a total volume of 5400 (cu in) deployed at $6 \pm 1 \mathrm{~m}$ depth (Geotrace, unpublished report PR4279, 2010). Parameters of acquisition and data resolution are presented in Table 1.

[12] PSDM was undertaken along profile Pegasus_19 to determine velocity structures and to image genuine geometries of structures involved in fluid expulsion toward the GHSZ. Raw seismic data are contaminated by multiple reflections at depths critical for imaging the subduction interface (Figure 1c). Consequently pre-processing was initially focused on removal of the multiples. For analysis at Opouawe Bank a second processing sequences was also carried out aiming at preserving the highest data resolution. Details of data preparation for PSDM are given in Text S1 in the auxiliary material. ${ }^{1}$

[13] A standard PSDM processing scheme was implemented [e.g., Hoffmann and Reston, 1992; Kopf, 1999] and described in Text $\mathrm{S} 2$ in the auxiliary material. The PSDM is performed iteratively, using updated $\mathrm{P}$ wave velocity models to improve subsequent migrated images. Depth conversion, iterative energy depth focusing analysis, velocity model smoothing, and ray tracing are performed between iterations of migration until a preferred image of the sub-structures is obtained [MacKay and Abma, 1992]. The final image and $\mathrm{P}$ wave velocity structure of Pegasus_19 resulted from five iterations and are shown in Figures 2 and 3, respectively.

\section{Results and Interpretation}

\subsection{Stratigraphy}

[14] To infer fluid sources and to constrain timing of structural development, fluid migration and evolution of the gas hydrate system, stratigraphic correlation was carried out involving line Pegasus_19 and surrounding seismic data. The stratigraphic interpretation was completed by correlating seismic reflectors, erosional unconformities, and onlap surfaces throughout the entire regional grid of standard 2D time-migrated Pegasus survey profiles (Figure 1). In addition, a suit of Late Miocene to recent dated sediment samples [Barnes, 1994a, 1994b; Barnes and Mercier de Lépinay, 1997], were used to

${ }^{1}$ Auxiliary materials are available in the HTML. doi:10.1029/ 2012GC004228. 


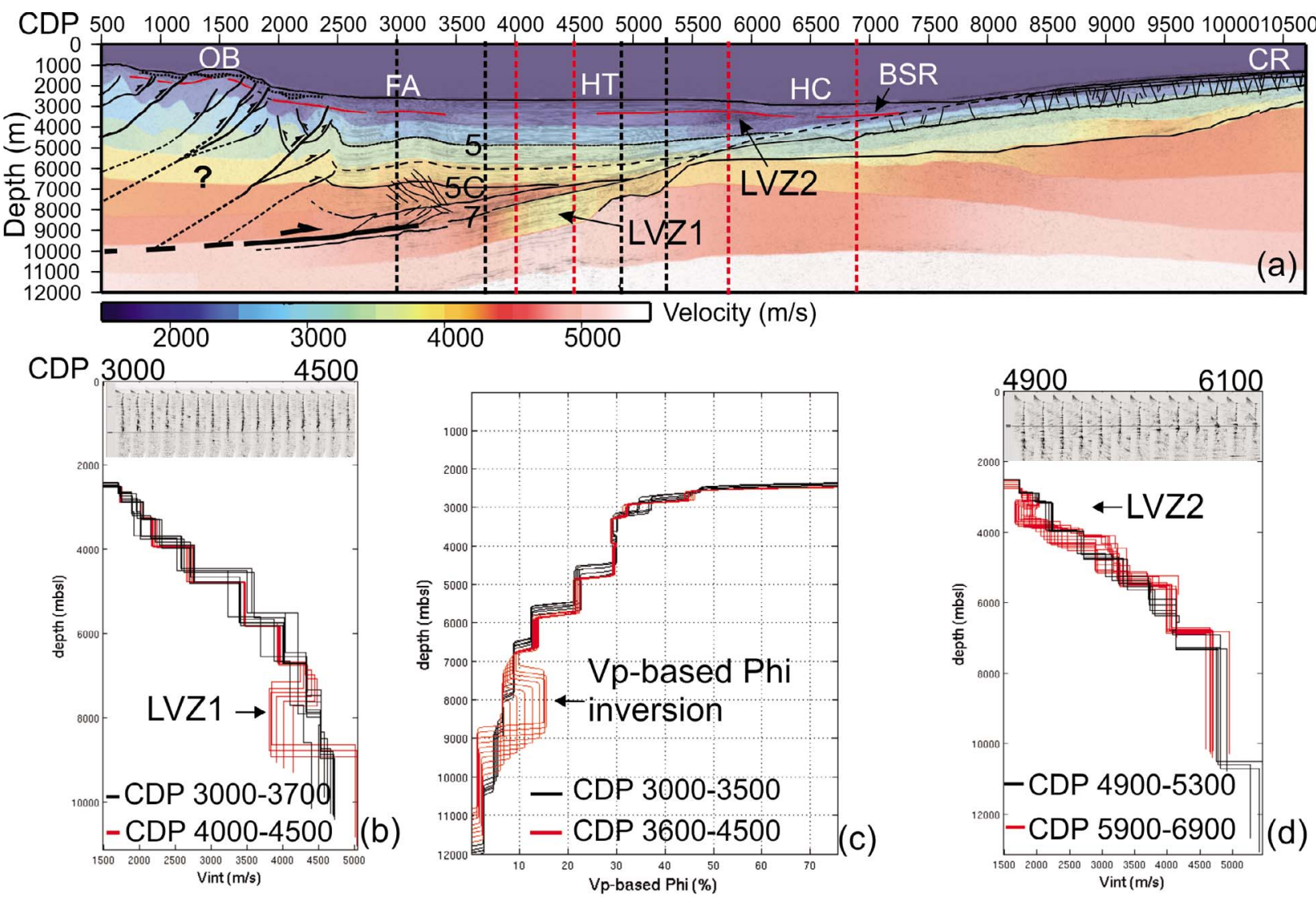

Figure 3. (a) Macro velocity model used for pre-stack depth migration with interpretation and seismic superimposed. OB: Opouawe Bank; FA: frontal anticline; HT: Hikurangi Trough; HC: Hikurangi Channel; CR: Chatham Rise; (b) $1 \mathrm{D}-\mathrm{Vp}$ curves for individual CDP gathers showing the magnitude of velocity inversion within LVZ1; (c) 1D-Vpbased porosity curves estimated from the empirical equations of Erickson and Jarrard [1998] for normally compacted trough sediments and $33 \%$ clay content. (d) $1 \mathrm{D}-\mathrm{Vp}$ curves for individual CDP gathers showing the magnitude of velocity decrease within LVZ2.

Table 2. Summary of Stratigraphic Interfaces Relevant for This Study

\begin{tabular}{|c|c|c|}
\hline Nomenclature & Estimated Age & Comments \\
\hline Paleo-seafloor_B & $200 \mathrm{kyr}$ & $\begin{array}{l}\text { If correlated with reflector } 2 \text { in Barnes and Mercier de Lépinay } \\
\text { [1997] }\end{array}$ \\
\hline Reflector 3 & $0.6 \pm 0.2 \mathrm{Ma}$ & $\begin{array}{l}\text { Previously inferred as } 0.8 \pm 0.2 \mathrm{Ma} \\
\quad[\text { Barnes and Mercier de Lépinay, 1997] }\end{array}$ \\
\hline $\begin{array}{l}\text { Reflector } 5 \\
\quad \text { (paleo seafloor_A) }\end{array}$ & Pleistocene (1.2-2.7 Ma) & $\begin{array}{l}\text { Previously inferred as } \sim 5.1 \mathrm{Ma} \\
\quad[\text { Barnes and Mercier de Lépinay, 1997] }\end{array}$ \\
\hline Reflector L & Early Pliocene $(\sim 3.5 \pm 0.2 \mathrm{Ma})$ & $\begin{array}{l}\text { Regional unconformity on NW Chatham Rise slope correlated } \\
\text { with NZ Stage Wo-Wp [Barnes, 1994a] }\end{array}$ \\
\hline Reflector 5B & Late Miocene (?) & $\begin{array}{l}\text { Regional onlap and erosional surface beneath southern and } \\
\text { central Hikurangi Trough }\end{array}$ \\
\hline Reflector 7 & Paleogene (?) & Located above Paleogene rocks of sequence $\mathrm{Y}$ \\
\hline Sequence $\mathrm{Y}$ & $\begin{array}{l}\text { Late Cretaceous-Early Paleogene } \\
\quad(70-32 \mathrm{Ma})\end{array}$ & Condensed sequence [Davy et al., 2008] \\
\hline Sequence MES & Late Cretaceous (100-70 Ma) & Equivalent with MES from Davy et al. [2008] \\
\hline Reflector 8 & Early Cretaceous (120-100 Ma) & Top of Hikurangi Plateau \\
\hline
\end{tabular}




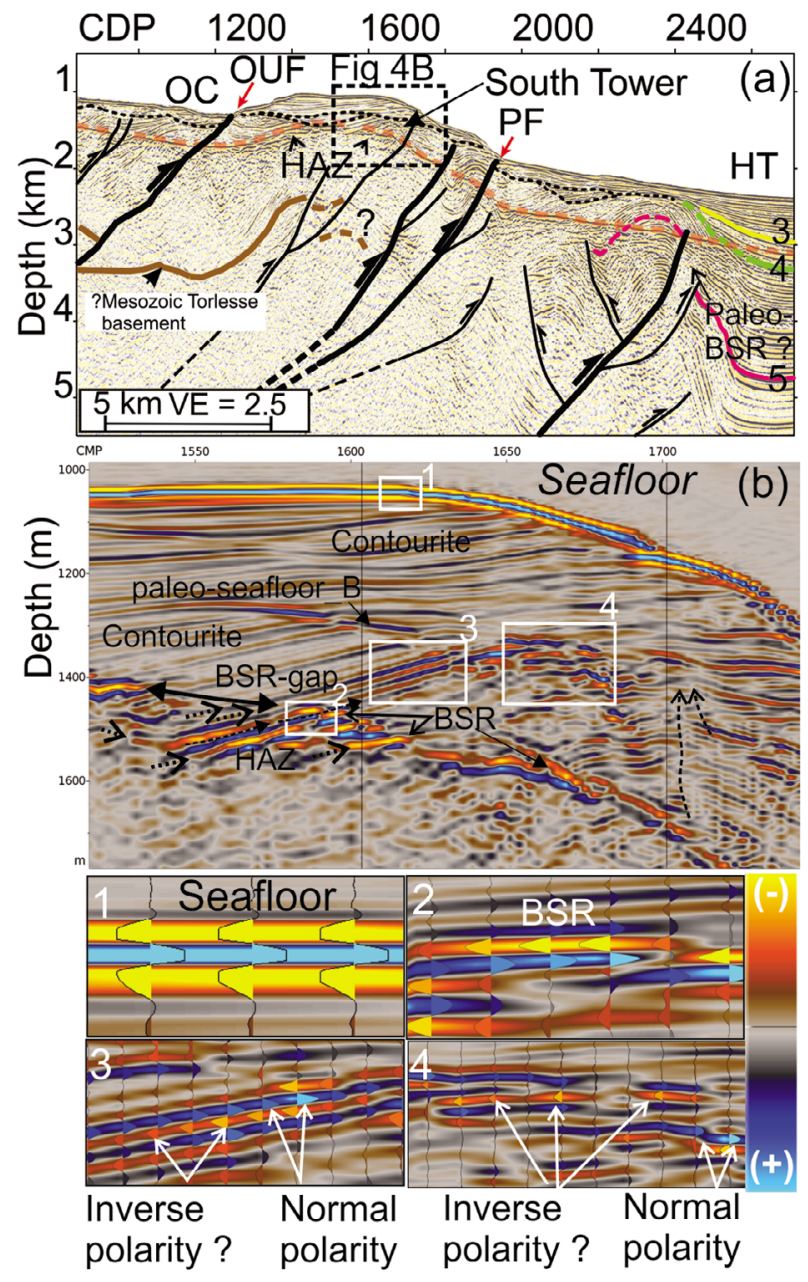

Figure 4. (a) Pre-stack depth migrated seismic section at Opouawe Bank showing structural and stratigraphic interpretation. $\mathrm{OC}=$ Opouawe Canyon, OUF $=$ Opouawe-Uruti fault, $\mathrm{PF}=$ Pahaua fault, $\mathrm{HT}=$ Hikurangi Trough, HAZ = high amplitude zone; (b) detailed region of the buried South Tower chimney cluster showing polarity of bright reflections (3 and 4) within the GHSZ compared to seafloor and BSR reflections (1 and 2).

constrain the age of unconformities. Results of this regional study will be presented elsewhere. Stratigraphic interfaces relevant for this study are summarized in Table 2. We adopted the stratigraphic framework of Barnes et al. [2010].

[15] Toward the Chatham Rise 1-2 km of Cretaceous sediments lies unconformably on the inactive Mesozoic Chatham Rise accretionary wedge (Figure 2). The upper $\sim 1.0-1.5 \mathrm{~km}$ of sediments are inferred to be Miocene to present. This includes the Late Miocene reflector (LM) and late Early Pliocene reflector (L) unconformities (Table 2). This sequence is highly condensed in comparison with the equivalent age from the Hikurangi Trough sediments and is strongly deformed by faulting (Figure 2).

[16] We traced the 23.5 Ma old regional unconformity (reflector L) from the Chatham Rise downslope into the Hikurangi Trough. Reflector $\mathrm{L}$ potentially diverges into the trough sequence about $6 \mathrm{~km}$ below sea level (kmbsl), or may extend deeper to correlate directly with onlap surface 5B at about $7 \mathrm{kmbsl}$ toward the center of the trough (Figure 2b). Taking into account the uncertainty of these correlations, the time-averaged rate of sediment accumulation above reflector $\mathrm{L}$ is about $1-1.3 \mathrm{~km} / \mathrm{Myr}$. Ages estimated using this rate are generally consistent with ages of shallower reflectors estimated from mid Pliocene to Pleistocene samples recovered from uplifted exposures of the equivalent sequence above reflector 5 north of the profile (Table 2).

[17] Beneath the wedge of Hikurangi Trough turbidites [Barnes et al., 2010], 3-3.5 km of Cretaceous and Paleogene strata are being subducted with a décollement located at $\sim 10 \mathrm{kmbsl}$. The décollement is inferred to lie above a condensed sequence of strongly reflective Late Cretaceous-Early Oligocene (70-32 Ma) sediments [Wood and Davy, 1994; Davy et al., 2008]. This sequence, referred to as sequence $\mathrm{Y}$, has been widely recognized and tied to borehole data from the eastern edge of the Hikurangi Plateau at ODP site 1124, where it comprises nannofossil chalks and alternating mudstones [Davy et al., 2008]. The top of sequence $\mathrm{Y}$ is defined by a high amplitude reflector with a high impedance contrast (reflector 7 in Figures 2 and S4). Sequence $\mathrm{Y}$ is relevant for our study due to its potential role as a seal for migrating fluids from beneath the subduction interface.

[18] The stratigraphy above the basement, beneath Opouawe Bank, likely includes Cretaceous and Paleogene sequences equivalent to those exposed in nearby coastal hills [Begg and Johnston, 2000], as well as a $\sim 0.5-1.0 \mathrm{~km}$ thick Late Cenozoic, mudstone-dominated cover sequence. The upper $\sim 800 \mathrm{~m}$ reveals sediment drift-like architecture, possibly associated with former contourites (Figure 4). At the location of South Tower, an active methane seep site [SO-214 Scientific Party, 2011], an erosion surface at $\sim 250 \mathrm{mbsf}$ may correlate approximately with a reflector in the Hikurangi Trough inferred to be about $200 \mathrm{kyr}$ old (Table 2). This age estimate at the bank is probably a minimum, as some sediment erosion is expected. Furthermore, if average sedimentation rates at the bank are lower than in the 
Hikurangi Trough, and of the order of $0.3 \mathrm{Km} / \mathrm{Myr}$ [e.g., Lewis, 2009], the $250 \mathrm{~m}$ deep unconformity at the Opouawe Bank could be as old as $\sim 0.8 \mathrm{Ma}$.

\subsection{The Active Southern Hikurangi Subduction Margin}

[19] Along Pegasus_19 the offshore part of the active Hikurangi margin is about $35 \mathrm{~km}$ wide (Figures 2 and S1). The NW part of the profile reveals complex thrust faulting and folding beneath the Wairarapa slope with at least seven major NW-dipping faults imaged, several of which reveal complex imbrications in the upper 2-4 km beneath the seafloor (Figure 4a). These faults have an average dip of about $22-23^{\circ}$ and include the active Opouawe-Uruti and Pahaua faults [e.g., Mountjoy et al., 2009]. Refractions recorded by long offsets and causing strong energy picks associated with anomalously high velocities beneath Opouawe Bank suggest the presence of a significant lithology contrast that we interpret to be the contact between the deformed cover sequence and the Mesozoic (Torlesse) basement, at about 2-3 km depth at the NW end of the line (Figures 2 and $4 a$ ).

[20] Below Opouawe Bank only a few coherent reflections are imaged, such that the downdip extent (i.e. $>4-5 \mathrm{~km}$ depth) of major thrust faults in the upper plate are not well resolved (Figure 4a). Beneath the lower slope, SE of the Pahaua Fault, coherent reflections up to $7 \mathrm{kmbsl}$ reveal complexly faulted and folded Plio-Pleistocene stratigraphy of the Hikurangi Trough (Figures 2 and 4a). Active faulting is evident well into the late Pleistocene, as revealed by growth stratigraphy on the flanks of a major anticlinal complex at about CDP 2350 (Figure 4a). The deeper thrusts within the SE edge of this complex have tips at 3-4 $\mathrm{km}$ depth and appear to be inactive, indicating progressive hanging wall imbrication. Complexity of the shallow imbricates, including at least two backthrusts, results in asymmetric folds with wavelengths of $1-2 \mathrm{~km}$. Flat reflections crosscutting folded strata, possibly corresponding to paleo-BSRs, are restricted to these imbricated inactive thrust region (Figure $4 \mathrm{a}$ ).

[21] The position of the décollement is interpreted at $9.0-9.5 \mathrm{kmbsl}$. The décollement appears to lie $700-800 \mathrm{~m}$ beneath a major regional onlap surface (reflector 5B) at or near the base of the Hikurangi Trough turbidites (Figure 2). This position is consistent with the stratigraphic level at which the frontal part of the plate interface is developed up to $250 \mathrm{~km}$ further North, offshore Cape Turnagain
(Figure 1) [Barnes et al., 2010]. Below the décollement $3.0-3.5 \mathrm{~km}$ of normal-faulted Cretaceous and Paleogene strata (Figure 2, sequences MES and $\mathrm{Y}$ ), are subducting together with underlying oceanic rocks of the Hikurangi Plateau (reflector 8).

\subsubsection{Seismic Character of the Opouawe Bank}

[22] The GHSZ, as determined by the presence of a BSR, is $500 \mathrm{~m}$ thick at Opouawe Bank. The BSR appears as a reverse polarity reflection crosscutting NW-dipping well stratified contourite sequences (Figure 4a). NW-dipping reflections extend beneath the BSR forming two distinctive high amplitudelow frequency zones (HAZ) $\sim 100 \mathrm{~m}$ thick and 1.5$2 \mathrm{~km}$ long. A gap of $\sim 300 \mathrm{~m}$ in the BSR separates the two high amplitude zones (Figure 4b). A subtle decrease in $\mathrm{Vp}$ of $\sim 5 \%$ above the BSR at CDPs $1400-1500$ with respect to adjacent $\mathrm{Vp}(1800 \mathrm{~m} / \mathrm{s}$ versus $2000 \mathrm{~m} / \mathrm{s}$ ) is interpreted to result from inclusion of low velocity material from beneath the BSR into the overlying velocity domain.

[23] At the location of the BSR-gap a stack of 4-5 high amplitude dipping reflectors reappear within the contourite infill approximately $100 \mathrm{~m}$ above the BSR (Figure 4b3). Whether these high amplitude reflections show reverse polarity is uncertain. However, a gentle downdip change in polarity (i.e., from normal polarity updip to inverse polarity downdip) is perceived when comparing in detail the signatures along the reflections (Figure 4b3). A polarity inversion is clearer at bright reflections toward the top of the buried chimney cluster associated with South Tower (Figure 4b4).

\subsection{The Frontal Growing Anticline}

[24] An anticline developing in approximately $2400 \mathrm{~m}$ water depth toward the thickest part of the Hikurangi Trough ( CDP 3190), represents a recent forward propagation of the plate interface décollement into the trough sequence (Figure 2). Above the tip of the décollement, a $\sim 10 \mathrm{~km}$ wavelength growing fold exhibits a maximum amplitude (vertical structural elevation) of reflectors within the folded strata of $\sim 400 \mathrm{~m}$ (Figure 5a). The fold is associated with a bathymetric ramp, about $85 \mathrm{~m}$ high, on the otherwise flat seafloor. Two arrays of opposite verging proto-thrusts define a thrust triangle zone and accommodate shortening at the base of the anticline. These features are best imaged in a time-migrated version of the section with higher spatial resolution (Figure 5b). Each array of protothrust affects sedimentary sequences $\sim 900 \mathrm{~m}$ and 

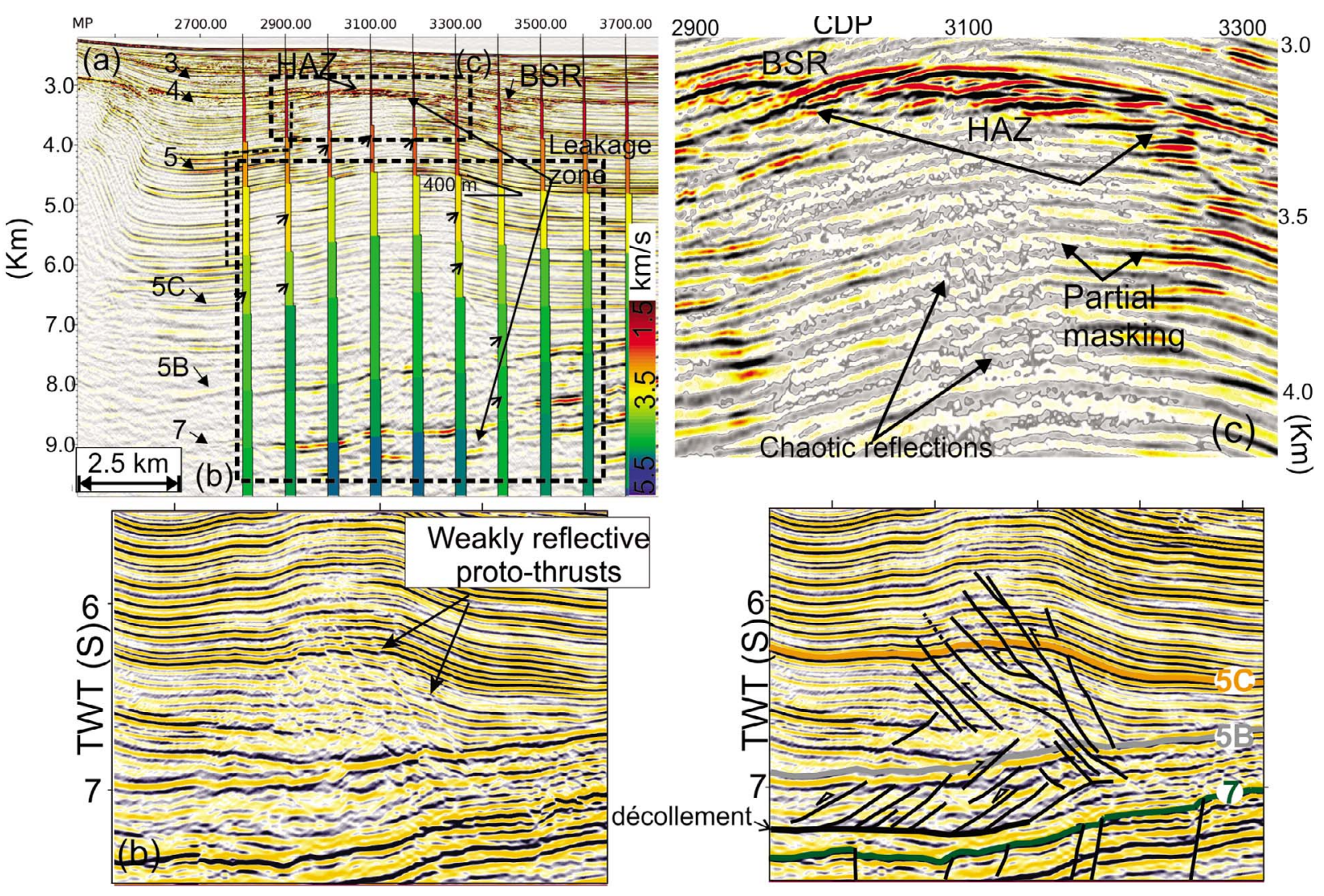

Figure 5. (a) Pre-stack depth migrated seismic section from the frontal anticline region. 1D-Vp curves are superimposed to show lateral $\mathrm{P}$ wave decrease at some locations coinciding with dim-amplitude anomalies (short arrows). Dotted line shows a change in the extent of seismic blanking at the depth of reflector 5; (b) enlarged region (uninterpreted left and interpreted right) at the base of the anticline from a time migrated processed stack (two-way-time) with higher spatial resolution showing details of the proto-thrusts; (c) display of the upper part of the anticline showing deformation of primary bedding and seismic blanking.

$2 \mathrm{~km}$ thick beneath and above reflector $5 \mathrm{~B}$ respectively (Figures 2 and 5).

\subsubsection{Seismic Character of the Frontal Anticline}

[25] The BSR is at around $700 \mathrm{mbsf}$ at the frontal anticline. A HAZ $\sim 150 \mathrm{~m}$ thick and $4.5 \mathrm{~km}$ long appears restricted to the center of the anticline beneath the BSR. Vertical zones of seismic blanking characterize sediments at the flanks and the center of the anticline beneath the HAZ (Figure 5a). Blanking within $2 \mathrm{~km}$ of sediments beneath the BSR is restricted to the lateral extension of the HAZ. Reflections within the blanking zone are continuous and undisturbed toward the flanks but chaotic and deteriorated at the center of the anticline (Figure 5c). Common offset sections for large offsets show that blanking persists with depth. The zone affected by blanking gets narrower above reflector 5 (Figures 2 and 5a). Blanking zones coincide with $\mathrm{Vp}$ decreases by $\sim 7 \%$ for some CDPs in the anticline region (e.g., CDDs 2800, 2900, 3400) compared to velocities outside (Figure 5a).

[26] Blanking can be traced down to the Cretaceous sequence underlying reflector 7 and sequence $Y$ (Figure 6). To the east blanking extends down to a $60^{\circ}$-dipping normal fault with vertical offset of $\sim 300 \mathrm{~m}$, in the subducting Cretaceous sequence (Figure 6b). Normal faulting affects sequence $\mathrm{Y}$ and reflector SC, a reflector $500 \mathrm{~m}$ beneath sequence $\mathrm{Y}$. In the footwall of the fault both sequence $\mathrm{Y}$ and SC are characterized by anomalous high amplitudes and SC shows polarity reversal. In the hanging wall, amplitudes of both reflectors decrease and the polarity of SC loses clarity, suggesting a lateral change in polarity along SC (Figure 6b). 

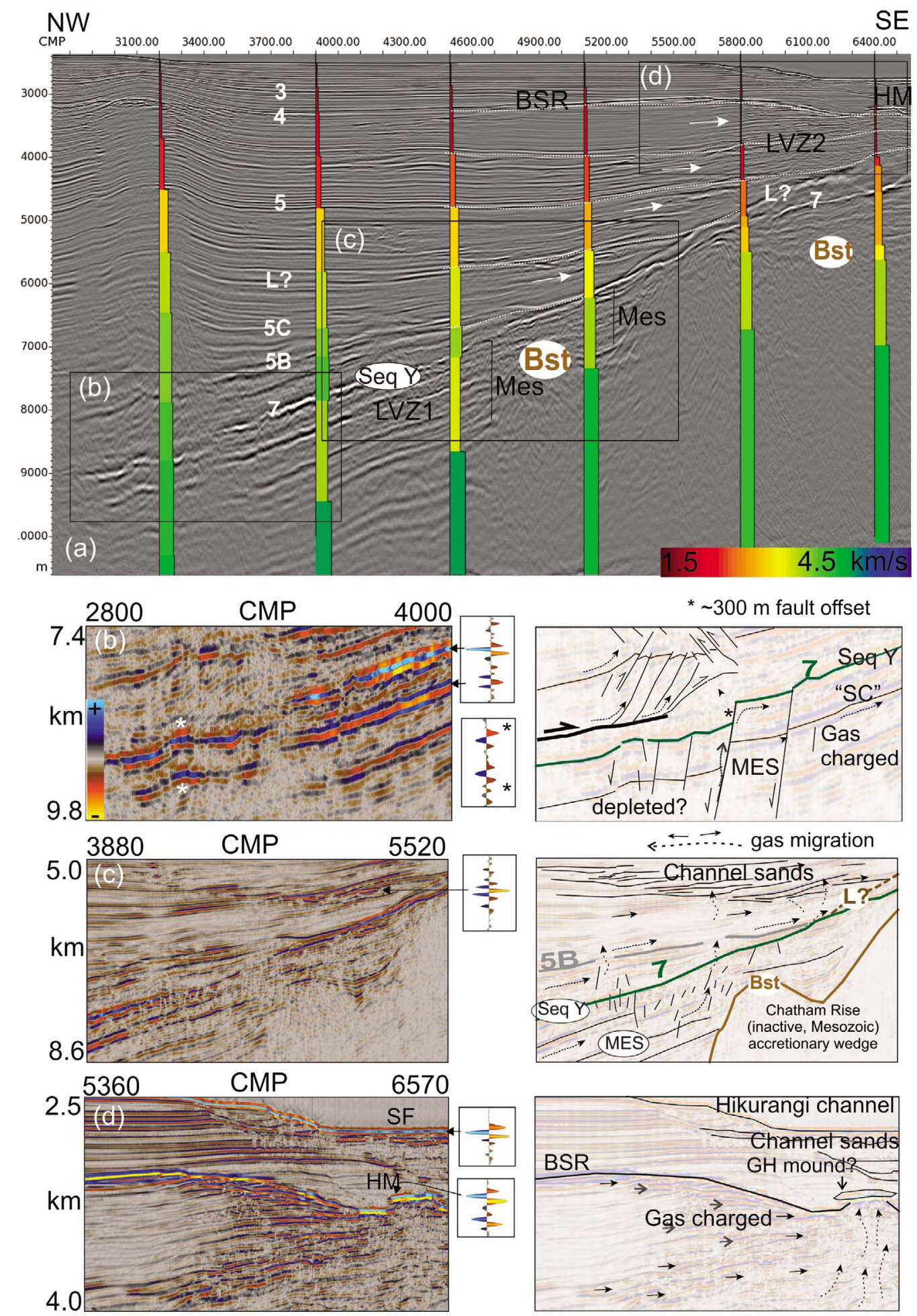

Figure 6. (a) Pre-stack depth migrated seismic section from the Hikurangi Trough showing location of zones with Vp inversion (LVZ1 and LVZ2) and lateral Vp decrease (white arrows). Interval velocities are superimposed; (b) display of faulted underthrust sediments (uninterpreted left and interpreted right) beneath the frontal anticline including high-amplitude sequence Y and underlying high amplitude-reverse polarity reflection (wiggle panels) SC; (c) display of vertical dim-amplitude anomalies and lose of continuity of bright reflections indicating a potential pathway for fluids between LVZ1 and LVZ2; (d) detail display of bright reflections associated with buried channel sands and gas injection into the hydrate zone at the location of an interpreted hydrate mound (HM). 


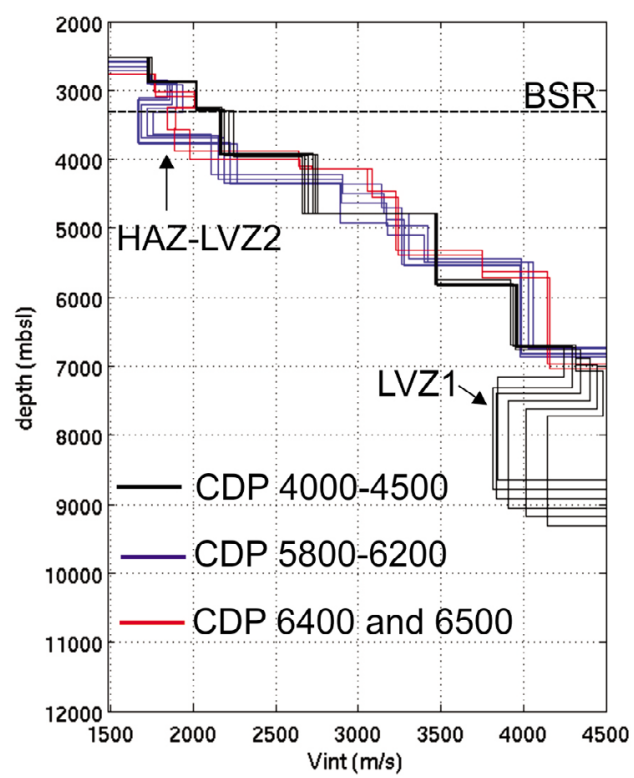

Figure 7. Velocities for individual CDP gathers showing Vp of sediments above the base of the GHSZ. CDPs 4000-4500 (black) are in a region where no high amplitude zones (HAZ) or low velocity zones (LVZ) are observed in the seismic; CDPs 5800-6200 (blue) are within the anomalous HAZ-LVZ2. CDPs 6400 and 6500 (red) are at the location of the HM reflection (see Figure $6 \mathrm{~d}$ for location).

[27] Within the $\sim 1.5 \mathrm{~km}$ thick velocity domain beneath sequence $\mathrm{Y}, \mathrm{Vp}$ show a lateral decrease in velocity and velocity inversion with respect to overlying interval velocities (Figures $3 \mathrm{a}$ and $3 \mathrm{~b}$ ). $\mathrm{Vp}$ is $\sim 4.4 \mathrm{~km} / \mathrm{s}$ beneath the frontal anticline and decreases updip, reaching a minimum of $\sim 3.6 \mathrm{~km} / \mathrm{s}$. With respect to the overlying interval velocities this represents an inversion of $250-500 \mathrm{~m} / \mathrm{s}$ for consecutive CDPs between CDP 3800-4700 (Figures 3b and $6 \mathrm{a})$. We refer to this zone as low velocity zone 1 (LVZ1). This Vp domain comprises the high amplitude-reverse polarity reflection SC. The velocity inversion terminates against sediments from the former Chatham Rise deformation front and has an apparent lateral extension of $\sim 8 \mathrm{~km}$ (Figure 3a).

\subsection{The Hikurangi Channel and Buried Channel System}

[28] The Hikurangi Trough sequence above the regional onlap surface $5 \mathrm{~B}$ is up to $5.6 \mathrm{~km}$ thick (Figure 2). This sequence is characterized by stacked high-amplitude channel sands, channel-levee sediments and local unconformities, reflecting the longterm evolution of the Hikurangi Channel turbidite system. Buried channel sands appear as a vertical stack of high amplitude reflections. The density of bright reflections is high beneath the western flank of the modern Hikurangi channel and extends down to the lower slope of the Chatham Rise (Figures 2 and 6), reflecting location of the channel preferentially on the SE side of the trough through time [Lewis and Pantin, 2002].

[29] At $\sim 7 \mathrm{~km}$ from the eastern flank of the frontal anticline the BSR gets weaker or disappears for $\sim 10 \mathrm{~km}$ (i.e., CDPs 3600-4600). It reappears at $\sim 500$ mbsf close to the Hikurangi Channel, crosscutting sedimentary structures (Figure 6a). A high amplitude zone $\sim 100 \mathrm{~m}$ thick and $\sim 15 \mathrm{~km}$ long appears beneath the BSR at the western margin of the modern Hikurangi Channel (Figure 6d).

[30] Between reflector L and the Chatham Rise unconformity two vertical dim amplitude anomalies and localized absence of reflectors appear rooted at sequence $\mathrm{Y}$ and extends upward into overlying Quaternary strata (Figure 6c). Within the velocity domain directly below the BSR a velocity inversion occurs. $P$ wave velocities are $170-250 \mathrm{~m} / \mathrm{s}$ lower than in the overlying interval (Figures $3 d$ and $6 a$ ). We refer to this zone as LVZ2. In addition to Vp inversion, $\mathrm{Vp}$ decreases laterally from the center of the Hikurangi Trough (undisturbed Vp $>2250 \mathrm{~m} / \mathrm{s}$ at $3 \mathrm{kmbsl}$ ) toward the channel flank where the LVZ is characterized by velocities as low as $1600 \mathrm{~m} / \mathrm{s}$. Along the three subsequently deeper $\mathrm{Vp}$ domains in the macro velocity model, velocities also show a trend of lateral decrease from the middle of the trough toward the Chatham Rise (Figure 3).

[31] A particularly bright normal-polarity reflection $\sim 2.3 \mathrm{~km}$ long (HM in Figure 6a) appears to be shifted upward $\sim 100 \mathrm{~m}$ with respect to the BSR where buried channel sands converge beneath the modern Hikurangi channel (Figure 6d). Interval Vp at the location of HM (i.e., CDPs 6400 and 6500) is $2000 \mathrm{~m} / \mathrm{s}$, the reported $\mathrm{Vp}$ above the expected base of the GHSZ where HAZ-LVZs are not observed in the seismic (e.g., CDP 4000-4500) (Figure 7). No anomalous $\mathrm{Vp}$ decrease is observed for the velocity domain comprising HM. Blanking and chaotic reflections characterize the sediments underlying $\mathrm{HM}$ and the stack of buried paleo-channel sands (Figure 6d).

\section{Discussion}

\subsection{Low Velocity Zones-LVZ1 and LVZ2}

[32] The shallow LVZ2, being restricted to the HAZ beneath the BSR (Figure 6d) is a widely used seismic 

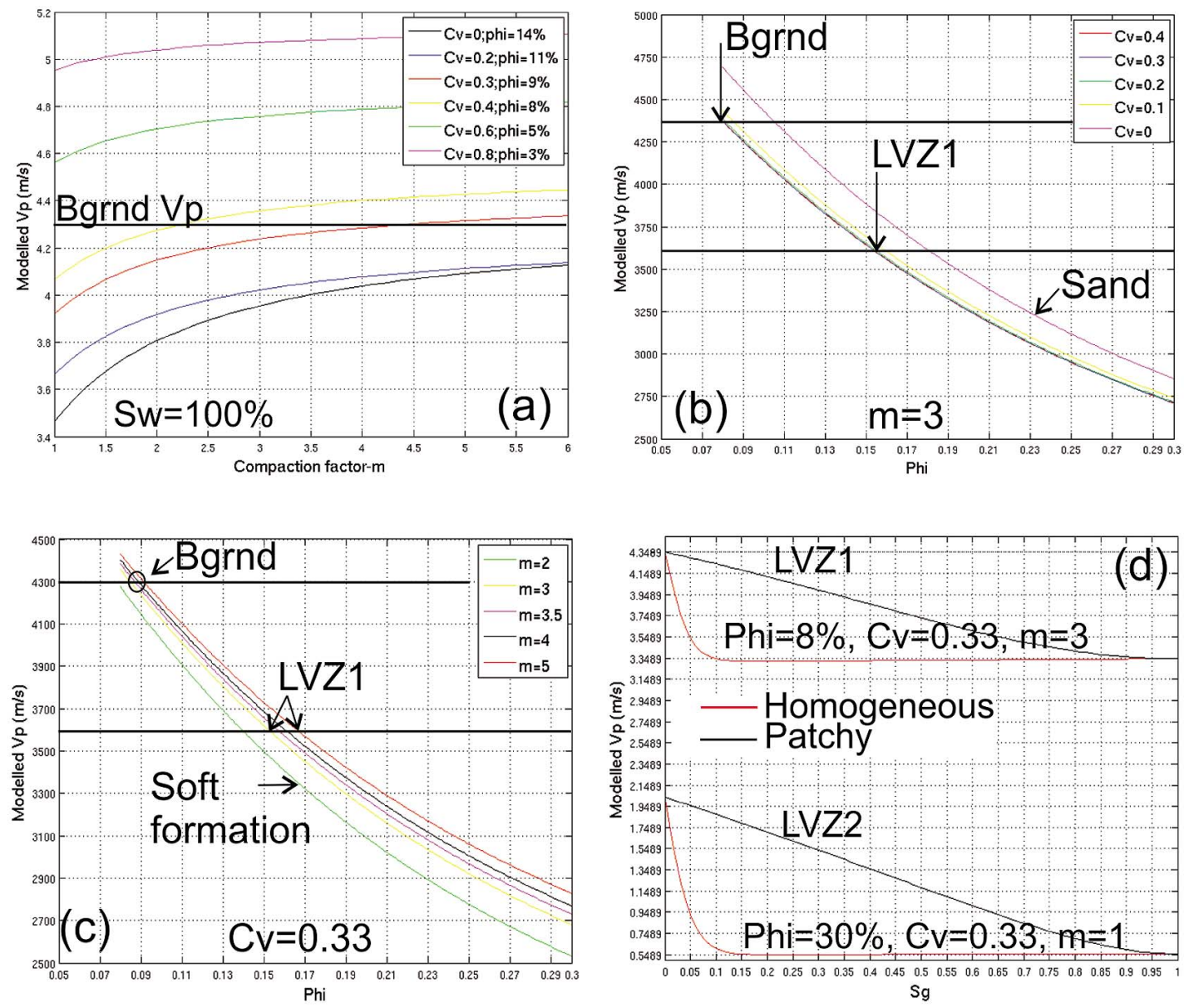

Figure 8. (a) Modeled Vp versus consolidation factor (m) for Vp-based porosity (Ø) and clay content (Cv) pairs from Erickson and Jarrard [1998]. Background velocity (i.e., outside LVZ1) (Bgrnd Vp) is $4.3 \mathrm{~km} / \mathrm{s}$; (b) modeled $\mathrm{Vp}$ versus $\varnothing$ for fixed $\mathrm{m}$ but variable $\mathrm{Cv}$; (c) modeled Vp versus $\varnothing$ for fixed $\mathrm{Cv}$ but variable m; (d) modeled Vp versus gas saturation Sg within LVZ1 (above) and LVZ2 (below) for homogenous and patchy gas distributions.

indicator of free gas trapped beneath hydrate bearing sediments (e.g., Bangs et al. [1993]; Holbrook et al. [1996]; Bünz and Mienert [2004]; Hornbach et al. [2004]; Plaza-Faverola et al. [2010]; among many others). In general, high-amplitude reverse polarity reflections and its coincidence with $\mathrm{Vp}$ inversion are common seismic indicators of free gas charged sediments [e.g., Taylor et al., 2000; Vanneste et al., 2001; Løseth et al., 2009]. This relationship has been confirmed by drilling at the depths of BSRs at several gas hydrate provinces [e.g., Bangs et al., 1993; Holbrook et al., 1996]. Hence, LVZ2 can be interpreted as preferential accumulation of gas beneath low permeability hydrate bearing sediments. Depending largely on how evenly gas is distributed in the sediments, saturations between $<2 \%$ and $27 \%$ of pore volume would explain the observed $\mathrm{Vp}$ decrease within LVZ2, (Appendix A and Figure 8d).

[33] LVZ1 located at $>5 \mathrm{kmbsf}$ (Figures 2 and 3) requires some additional considerations since sediment compaction is likely to affect the physical rock properties. We perform semi-empirical rock physics modeling based on the equations by Lee [2004] to investigate the effect of compaction and gas saturation on $\mathrm{Vp}$ in sediments at the depth of LVZ1 (Appendix A). As a starting model we used the empirical relation between clay content $(\mathrm{Cv})$, $\mathrm{P}$ wave velocity $(\mathrm{Vp})$ and porosity $(\varnothing)$ for marine siliciclastic sediments from Erickson and Jarrard [1998], referred to as E\&J. We assume that the general trend of relation between $\mathrm{Vp}, \mathrm{Cv}$ and $\varnothing$ from $\mathrm{E} \& \mathrm{~J}$ is valid for normally compacted non gas bearing turbidite sediments of the Hikurangi Trough adjacent to LVZ1, where sediments show little or non-accretion (Figure 2).

[34] Only $\mathrm{Cv}$ values between 0.3 and 0.4 with respective $\varnothing$ pairs, for compaction factors (m) between 2 and 4, allowed modeling the background $\mathrm{Vp}$ of $4.3 \mathrm{~km} / \mathrm{s}$ (Figure $8 \mathrm{a}$ ). Above $10 \%$ of clay content, modeled $\mathrm{Vp}$ versus porosity curves are 
nearly similar for a given degree of compaction (Figure $8 b$ ) suggesting that modeled $\mathrm{Vp}$ is not significantly susceptible to uncertainties in $\mathrm{Cv}-\varnothing$ pairs.

[35] Assuming 100\% water saturation the model predicts a range of porosity increase from $8.5-9 \%$ to $15.5-16.8 \%$ (i.e., depending on the degree of compaction for an average clay content of 0.33 ) to explain a Vp decrease from $4.3 \mathrm{~km} / \mathrm{s}$ (background) to $3.6 \mathrm{~km} / \mathrm{s}$ (within LVZ1) in sediments at $8 \mathrm{kmbsf}$ and $2.5 \mathrm{~km}$ water depth (Figures $3 \mathrm{c}$ and $8 \mathrm{c}$ ). The predicted magnitude of porosity increase is comparable to reported porosity increases for other margins (i.e., $30-60 \%$ porosity increases), inferred to be caused by undercompaction of subducting sediments (e.g., Barbados [Bangs et al., 1990; Westbrook, 1991; Moore et al., 1998; Hayward et al., 2003], Nankai [Hyndman et al., 1993; Screaton et al., 2002; Bangs et al., 2009; Tobin and Saffer, 2009], Ecuador [Calahorrano et al., 2008]).

[36] Undercompaction may be thus an explanation to LVZ1 provided that sequence Y (Figure 2) acts as a seal and as a result inhibits the release of pore water to the trough. However, inferred porosities for LVZ1 are about half of reported porosities for undercompacted-underthrust sediments in other margins (i.e., usually above $30 \%$ ). It is furthermore difficult to understand why undercompaction would be restricted to pre-underthrust sediments (Figure 3a) (e.g., well data show an exponential decrease in porosity for analogous pre-underthrust sediments in the Nankai Trough [Screaton et al., 2002]).

[37] Given the likelihood of thermogenic generation in Cretaceous sediments (C. Uruski and K. Bland, Pegasus Basin and the prospects for oil and gas, unpublished petroleum report PR4326, GNS Science Consultancy Report 2010/291, Ministry of Economic Development, Wellington, New Zealand, 2011), discussed later (section 5.4), another explanation to LVZ1, consistent with its location, magnitude and extent, is the presence of low amounts of gas together with an updip increase in gas content. Whereas porosities close to $100 \%$ would be required to explain velocity inversions by the presence of water alone [Domenico, 1974], small amounts of free gas (i.e., $5 \%$ ) homogenously distributed in the porous space would be enough to explain the Vp decrease to a minimum of $3.6 \mathrm{~km} / \mathrm{s}$ at the depth of LVZ1 (Figure 8d).

\subsection{Fluid Migration Paths}

[38] Beneath Opouawe Bank, where the basal décollement is at $\sim 10 \mathrm{~km}$ depth (i.e., burial is $\sim 8.5 \mathrm{~km}$ ), thrust faults are major paths for deep fluids into the GHSZ (Figure 2 and 4). Younger sediments being accreted above the décollement are dewatering and undergoing compaction and strain hardening processes. It is well known from this and many other analogous subduction margins that part of the drained fluids migrate laterally and vertically, potentially through the basal décollement [Saffer and Screaton, 2003; Saffer and Tobin, 2011; Vannucchi et al., 2012], and toward the seafloor through thrust faults, fractures, and dipping permeable layers [Henry et al., 2002] (Figures 2 and 4). A widespread direct relationship between major thrust faults and active methane seep sites on the Hikurangi margin and elsewhere has been demonstrated [e.g., Bruhn et al., 2000; Henrys et al., 2009; Barnes et al., 2010; Pecher et al., 2010].

[39] Active seeps at Opouawe bank are located on the hanging wall of one of the main active thrust fault, the Pahaua Fault [Barnes et al., 2010]. One of the active seeps, South Tower [Netzeband et al., 2010; Schwalenberg et al., 2010; SO-214 Scientific Party, 2011], is underlined by thrust faults conceivably inactive at present but terminating close to the base of the GHSZ (Figure 4). Periodicity in active seeps is suggested to be controlled by rates of past and present fluid flux through thrustfaults [Netzeband et al., 2010] and lapses of excess pore pressure generation beneath the base of the GHSZ triggering chimney formation.

[40] At the frontal anticline migration of fluids from buried and subducting sediments is inferred to occur through normal faults, proto-thrusts and fractures. Blanking beneath the HAZ at the center of the anticline (Figures 2 and 5) indicates energy absorption at a zone of gas bearing sediments beneath the BSR. Vertical dim amplitude anomalies and chaotic reflections at the flanks and center of the anticline (Figures 2 and 5c) suggest structurally induced fracturing and post-depositional deformation of primary bedding related to the migration of overpressured fluids [e.g., Løseth et al., 2009, 2010; Moss and Cartwright, 2010]. Similar deep rooted vertical zones of seismic blanking associated with tectonically driven sediment deformation have been observed farther north along the Hikurangi margin and suggested to be preferred paths for focused fluid escape [Crutchley et al., 2011].

[41] We hypothesize that normal faults, underlying the stack of protothrusts at the base of the anticline and fractures at its flanks (Figure 6b), have facilitated depletion not only of pore water during 

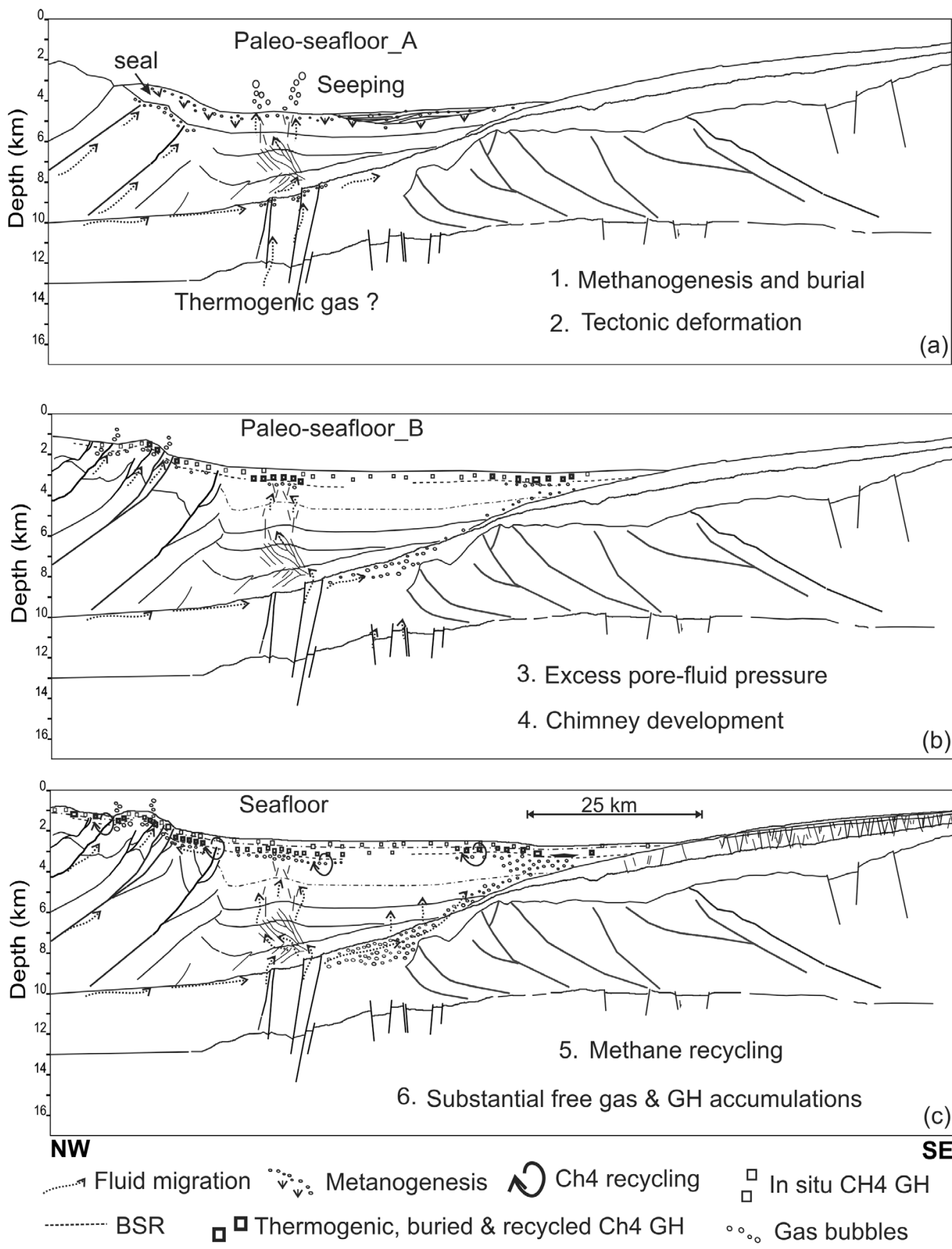

Figure 9. Conceptual model showing the evolution of fluid flow and gas hydrate systems across southern Hikurangi margin. Three main stages of evolution based on dominant processes for methane supply are presented. See text for full explanation of the evolution.

compaction [Hyndman et al., 1993; Moore et al., 1998; Bangs et al., 1999; Screaton et al., 2002] but also gas from potential thermogenic accumulations in Cretaceous subducting sediments (section 5.4). These fluids have been accumulating at the crest of the anticline beneath the BSR (Figure 5). On the other hand, the lack of faults and integrity of sequence $\mathrm{Y}$ as a seal has conceivably made the same Cretaceous but pre-underthrust sediments (i.e., LVZ1), prone to fluid/gas accumulation (Figure 9). The bright amplitude reverse-polarity SC reflection within LVZ1 (Figure 6b) supports the notion of updip increases in gas content. Periodic increases in pore fluid pressure are expected toward the 
deformation front due to slow drainage but continuous recharge from updip migrating fluids [Bangs et al., 1999; Vannucchi et al., 2012]. The two vertical dim amplitude anomalies and chaotic reflections within the lower Hikurangi Trough sediments may be indicating potential drainage paths linking LVZ1 and LVZ2 (Figure 6c).

\subsection{Concentrated Hydrate Zones}

\subsubsection{Opouawe Bank}

[42] At Opouawe Bank the hydrate system is dynamic and unstable, characterized by intermittent gas escape through chimneys (Figure 4a). Electromagnetic data show gas hydrate concentrations close to zero outside chimneys, while they show high concentrations, between 13 and 34\% of total volume inside chimneys [Schwalenberg et al., 2010]. High resolution seismic data from the bank show that active seeps at South Tower are part of a cluster of several chimneys associated with the same focused fluid flow system. Some of the chimneys from this cluster have been active in the past, as indicated by their termination at the $250 \mathrm{mbsf}$ erosion surface (paleo seafloor_B, Table 2) (Figure 4b).

[43] The HAZs and lose of high seismic frequencies characterizing sediments beneath the BSR (Figure $4 \mathrm{~b}$ ) indicate accumulation of free gas beneath the GHSZ. The BSR gap west of South Tower may indicate a zone where gas is locally bypassing at present the base of the GHSZ. High amplitudes along dipping well-stratified reflectors terminating at the top of buried chimneys (Figure $4 \mathrm{~b}$ ) would be consistent with a current stage of coexistence of free gas with hydrates inside the GHSZ [ Liu and Flemings, 2007]. It is also possible that high amplitudes (Figures $4 \mathrm{~b} 3$ and $4 \mathrm{~b} 4$ ) indicate instead, a stage were gas is already trapped in hydrates similar to stratigraphy-controlled hydrate bearing turbidite channels of the Nankai Trough [Noguchi et al., 2011].

\subsubsection{Frontal Anticline}

[44] The presence of a concentrated hydrate zone at the frontal anticline (Figure $9 b$ ) is inferred from the existence of a clear BSR and underlying gas zone (Figure 5). The hydrate/free gas system is stable at present. Gas chimneys are not developed. However, a gas column beneath the BSR sustained by escaping fluids from underthrust sediments and cessation of lateral migration along the GHSZ may in time lead to overpressure [Hornbach et al., 2004] and chimney formation, making the system unstable and similar to Opouawe Bank.

\subsubsection{Buried Channel-Sands}

[45] Buried channel-sands beneath the modern Hikurangi Channel (Figure 6d) have the potential of accumulating important amounts of free gas and hydrates. The existence of a concentrated hydrate zone at this location is inferred from the existence of the wide HAZ-LVZ2 (Figures 3 and 6) and the exceptional HM reflector (Figure 6). It has been discussed whether HM may represent a gas-charged sandy layer. However, an anomalous decrease in Vp would be expected as observed for comparable size-buried gas-rich channel sands beneath the BSR (Figures 3 and 6). A Vp decrease is not observed (Figure 7). In addition HM appears like a rather strong normal polarity reflection (Figure 6d). It is therefore likely that $\mathrm{HM}$ is associated with the presence of fast material, more precisely, concentrated hydrate in buried channel-sand at the top of a gas injection zone.

[46] The mechanism forming and sustaining such a concentrated hydrate zone may be similar to the formation of hydrate mounds recently described from offshore Angola [Serie et al., 2012, and references therein]. Gas seems to converge by buoyancy from buried sediments toward a triangular trap formed by the interception of hydrate bearing sediments and dipping Chatham Rise unconformity (Figures 2, 6a, and 9c). Injection of fluid into LVZ2 may be driven by compaction of un-consolidated sediments triggering lateral deformation and sediment remobilization [Vannucchi et al., 2012], thus explaining the chaotic seismic character of the $2-3 \mathrm{~km}$ of sediments beneath the BSR (around CDP 6500, Figure 6d).

\subsection{Sources of Gas for Hydrate Formation Across Southern Hikurangi}

[47] Recent studies show that Quaternary microbial methane and upward migration of gas from beneath the GHSZ in addition to Holocene in situ generated methane is necessary to explain significant deposits of marine gas hydrates [Burwicz et al., 2011]. Furthermore, the importance of methane transport from buried sediments to form concentrated hydrates has been demonstrated from well data at Hydrate Ridge offshore Oregon [Claypool et al., 2006]. Seismic evidences for deep fluid migration as discussed above strongly suggest that re-incorporation into the GHSZ from buried sediments has been a major mechanism sustaining concentrated hydrate 
accumulations across the Hikurangi margin. In addition to gas migration through faults, methane recycling at the base of the GHSZ [e.g., Minshull and White, 1989; Haacke et al., 2007, 2008] and lateral gas migration along low permeability hydrate bearing sediments toward more permeable paths [Pecher et al., 2001] are mechanisms aiding re-incorporation of methane to form hydrates at Opouawe Bank, the frontal anticline and the Hikurangi Channel (Figure 9).

[48] Thermogenic gas if available, would also migrate into the GHSZ through faults and fractures as micro or macro seepage [Abrams, 2005], and add to buried microbial methane sources, controlling timing and distribution of hydrates [e.g., Abegg et al., 2007; Lorenson et al., 2011]. Although not proven yet, thermal modeling suggests that an active petroleum system with Cretaceous and Paleocene source rocks, at depths likely to generate hydrocarbons, exists in the subducting plate beneath the Hikurangi Trough at the location of LVZ1 [Uruski, 2010; Uruski and Bland, unpublished report, 2011]. Leakage of thermogenic hydrocarbons has been reported from Late Cretaceous-Paleocene marine source rocks onshore New Zealand's East Coast [Giggenbach et al., 1995; Field et al., 1997; Rogers et al., 1999]. These hydrocarbon-prone sequences are the onshore equivalent of the condensed sequence Y (Figure 2).

[49] We suggest, therefore, that gas in the low velocity zones is likely to have thermogenic components from subducting source rocks (Figures 2, 3, and 9). The question arises why thermogenic gas signature hasn't been seen in shallow samples from monitored seep sites at Opouawe Bank [Greinert et al., 2010; SO-214 Scientific Party, 2011]. Secondary microbial biodegration of thermogenic gases may be an explanation. Although the significance of the contribution of secondary microbial methane to the global carbon cycle remains poorly understood, recent studies show that secondary microbial methane may account for up to $11 \%$ (compared to $4 \%$ of primary microbial) of the global gas inventory where the majority of the gas is indeed thermogenic in origin [Milkov, 2010]. Within the upper tens of meters at Opouawe Bank (Figure 2) type I-methane hydrate accumulations may be partially sustained by secondary biodegraded microbial methane in addition to primary microbial methane, similar to complex hydrates from the Cascadia margin [e.g., Lu et al., 2007]. The signature of heavier methane and other thermogenic gases are expected to increase with depth.

\subsection{Timing of Fluid Expulsion and Hydrate Formation}

[50] We envisage the following evolution of fluid flow and concentrated hydrate zones across the southern Hikurangi margin (Figure 9):

[51] Stage A (1.2-2.7 Ma). Continuous microbial methane generation and downward propagation with burial initiated slow hydrate formation in places where in situ microbial methane concentrations had reached saturation. Toward Opouawe Bank, gas-rich fluids migrating upward along thrust faults would accumulate through time at the contact between the top Torlesse basement and fined-grained Pliocene cover sequences (Figure 9a). At a time of deposition prior to reflector 5 (Figure 2), shortening was accommodated by incipient proto-thrusting but not substantial folding near the present deformation front. We speculate that at this time leakage of thermogenic gas from subducting Mesozoic sediments to a former seafloor (paleo-seafloor_A) was facilitated by the development of the proto-thrusts.

[52] Stage B (600-200 kyr). An absence of growth strata until above reflector 3 (Figure $2 b$ ) indicates the frontal anticline had no significant geomorphic expression at any stage prior to about 600-200 kyr. Sedimentation rates higher than uplift rates may have led to rapid burial of Opouawe Bank and eventual sealing of the leakage zone at the frontal anticline. The inferred age of buried chimneys at Opouawe Bank and possible remnants of paleoBSRs within $\sim 300 \mathrm{~m}$ of sediments beneath the present-day base of the GHSZ (Figure 4) indicate that a dynamic system characterized by significant amounts of hydrate inside chimneys has been evolving for at least the last $200 \mathrm{kyr}$ (Figure 9b).

[53] Stage C (200 kyr till present). Methane recycling and re-incorporation of buried microbial methane into the GHSZ along thrust faults and fractures have been controlling gas hydrate formation rates. Concentrated hydrate zones are expected at zones of high fluid flux beneath the modern Hikurangi channel, the frontal anticline and the flanks of Opouawe Bank (Figure 9c). At focused but periodic high fluid flux areas (e.g., the South Tower chimney cluster), periods of hydrate dissociation are likely due to inhibitors such as excess salinity or excess methane concentrations. An observed link between BSRs and features that promote fluid flow on the Hikurangi Margin has led to the conceptual suggestion that thermogenic input may help sustain stable hydrate concentrations [Henrys et al., 2009]. We here see the most direct evidence so far for a potential 
thermogenic contribution to the gas hydrate system (Figure 9) on this margin. More detailed petroleum system modeling will be required to support these observations.

\section{Summary}

[54] Pre-stack depth migration of long-streamer multichannel seismic data facilitated the investigation of fluid flow regimes associated with both the deforming overriding plate and the subducting plate, controlling the distribution of concentrated hydrates across southern Hikurangi margin. Stratigraphic and structural interpretation of sedimentary sequences and faults down to $16 \mathrm{~km}$ depth revealed two preferred zones for fluid accumulation and migration pathways for drained underthrust and accreted sediments. A trend of velocity decrease updip in pre-underthrust Cretaceous sediments points toward an under-compacted zone or a gas rich zone. Free gas accumulations are expected beneath the BSR within sand rich turbidites of the Hikurangi Trough, the frontal anticline and the Opouawe Bank.

[55] Three main zones of concentrated hydrates are inferred to be sustained by focused fluid fluxes into the hydrate zone:

[56] 1. At Opouawe Bank the basal décollement is at approximately $10 \mathrm{~km}$ depth. Thrust faults facilitate re-incorporation of microbial methane and other fluids from buried sediments into the hydrate zone. Direct seismic evidence for thermogenic input into the hydrate system is lacking. Initiation of a dynamic hydrate system characterized by concentrated hydrate inside chimneys is inferred to date from 600 to $200 \mathrm{kyr}$ BP. Concentrated hydrates are expected inside chimneys and within dipping contourite sequences.

[57] 2. At the crest of the frontal anticline a zone of concentrated hydrates is inferred to be sustained by fluids leaking from drained buried and subducted sediments. In addition to reincorporation of microbial methane from buried sediments, thermogenic gas from potential deep Cretaceous and Paleogene reservoirs is leaking across the nascent subduction interface thrust at this locality. Both sources of gas are likely contributing to hydrate formation and lateral migration of gas along the base of the hydrate zone.

[58] 3. Beneath the modern Hikurangi Channel concentrated hydrates in buried channel sands are inferred to be sustained by gas injection into the hydrate zone. Fluids are anticipated to converge
Table A1. Elastic Constants Used for Modeling Gas Saturations

\begin{tabular}{lll}
\hline \multicolumn{1}{c}{ Parameter } & \multicolumn{1}{c}{ Value } & \multicolumn{1}{c}{ Reference } \\
\hline $\begin{array}{l}\text { Shear modulus of matrix } \\
\text { (quartz) }\end{array}$ & $44000 \mathrm{Mpa}$ & {$[$ Lee, 2004] } \\
$\begin{array}{l}\text { Bulk modulus of matrix } \\
\text { (quartz) }\end{array}$ & $38000 \mathrm{Mpa}$ & {$[$ Lee, 2004] } \\
$\begin{array}{l}\text { Density of matrix } \\
\text { (quartz) }\end{array}$ & $2650 \mathrm{Kg} / \mathrm{m}^{3}$ & {$\left[\begin{array}{c}\text { [Helgerud } \text { et al. }, \\
1999]\end{array}\right.$} \\
$\begin{array}{l}\text { Density of water } \\
\text { Bulk modulus of water }\end{array}$ & $1035 \mathrm{Kg} / \mathrm{m}^{3}$ & \\
$\begin{array}{l}\text { Density of gas } \\
\text { Bulk modulus of gas }\end{array}$ & $417 \mathrm{Kg} / \mathrm{m}^{3}$ & {$[$ Lee, 2004] } \\
\hline
\end{tabular}

from compacting trough sediments toward the hydrate zone. Thermogenic gases from the subducting plate are also inferred to reach this zone through connected permeable pathways.

[59] Methane sustaining hydrate formation across southern Hikurangi is most probably generated from mixed sources. Incorporation into the hydrate zone of microbial methane from buried-drained sediments through faults and fractures, recycling and lateral migration from oversaturated regions toward less saturated regions are expected to be processes controlling formation rates and distribution of hydrates at present. In addition, thermogenic gas supply from reservoirs beneath the subduction interface may have an important role accelerating gas hydrate formation by enhancing methane saturation levels at focused high-fluid fluxes into the hydrate zones.

\section{Appendix A: Modeling the Effect of Porosity and Gas Saturation on Vp}

[60] We applied Lee [2004] method to evaluate the effect of porosity and gas saturation on $\mathrm{P}$ wave velocities obtained from pre-stack depth migration. Lee's equations allow the incorporation of the effect of differential pressure, porosity and presence of gas in compressional velocity $(\mathrm{Vp})$ by implementing a modified Biot-Gassman theory coefficient (BGTL). $\mathrm{Vp}$ is calculated from the following elastic moduli equations:

Compressional velocity:

$$
V p=\sqrt{ }(\kappa+4 \mu / 3) / \rho
$$

Formation density:

$$
\rho=(1-\mathrm{K}) \rho_{\mathrm{ma}}+\mathrm{L} \rho_{\mathrm{fl}},
$$


where $\varnothing$ is porosity, $\rho_{\mathrm{ma}}$ is density of the matrix, and $\rho_{\mathrm{fl}}$ is pore fluid density.

Bulk modulus:

$$
\kappa=\kappa_{\mathrm{ma}}(1-\beta)+\beta^{2} \mathrm{M}
$$

where $\kappa_{\mathrm{ma}}$ is bulk modulus of matrix, $\beta$ is the Biot coefficient and $\mathrm{M}=1 /\left[\left((\beta-\varnothing) / \kappa_{\mathrm{ma}}\right)+\left(\varnothing / \kappa_{\mathrm{fl}}\right)\right]$ with $\kappa_{\mathrm{fl}}$ bulk modulus of the fluids.

Shear modulus:

$$
\mu=\mu_{\mathrm{ma}}(1-\beta),
$$

where $\mu_{\mathrm{ma}}$ is shear modulus of the matrix. The reader is referred to equations 9,11 and 13 in Lee [2004] for calculation of BGTL, $\rho_{\mathrm{fl}}$ as a function of gas saturation and $\kappa_{\mathrm{fl}}$ [Brie et al., 1995] respectively.

[61] Elastic constants used in our calculations are presented in Table A1. Parameters such as consolidation factor $(\mathrm{m})$, clay content $(\mathrm{Cv})$ and porosity (Ø) to model $\mathrm{Vp}$ as a function of gas saturation were chosen as average values from a range of values constrained by $\mathrm{Cv}$ - $\varnothing$ pairs from Erickson and Jarrard [1998] relation (see main text and Figure 8).

[62] $\mathrm{Vp}$ was modeled as a function of gas saturation with gas properties for methane at in situ pressuretemperature conditions using perfectly even and patchy distribution (Figure 8d). Gas properties were calculated from methane at estimated in situ pressure and temperatures [Gray, 1972; Parker, 1989; Duan et al., 1992].

\section{Acknowledgments}

[63] The research was supported by GNS Science's MSI funded contract C05X0908 'Gas Hydrates Resources', Marsden Fund project GNS0902 from the Royal Society of New Zealand, GNS's Direct Crown Funded Programme 'Petroleum Basin Research' and NIWA Core-OCOR1201. Multichannel seismic data were provided by New Zealand's Ministry of Economic Development (MED). We acknowledge the use of GLOBE Claritas ${ }^{\circledR}$ software and support from the Claritas team, especially from Andrew Juniper. We are thankful to Geomar for hosting APF and for making available their facilities for pre-stack depth migration. We thank Dorik Stow for discussions about contourite systems. Valuable comments from Miko Fohrmann, Karsten Kroeger, Harold Tobin and an anonymous reviewer helped us to improve the manuscript.

\section{References}

Abegg, F., G. Bohrmann, J. Freitag, and W. Kuhs (2007), Fabric of gas hydrate in sediments from Hydrate Ridge: Results from ODP Leg 204 samples, Geo Mar. Lett., 27(2-4), 269-277, doi:10.1007/s00367-007-0080-4.

Abrams, M. A. (2005), Significance of hydrocarbon seepage relative to petroleum generation and entrapment, Mar. Pet. Geol., 22(4), 457-477, doi:10.1016/j.marpetgeo.2004.08.003.

Bangs, N. L. B., G. K. Westbrook, J. W. Ladd, and P. Buhl (1990), Seismic velocities from the Barbados Ridge complex: Indicators of high pore fluid pressures in an accretionary complex, J. Geophys. Res., 95(B6), 8767-8782, doi:10.1029/ JB095iB06p08767.

Bangs, N. L. B., D. S. Sawyer, and X. Golovchenko (1993), Free gas at the base of the gas hydrate zone in the vicinity of the Chile triple junction, Geology, 21(10), 905, doi:10.1130/ 0091-7613(1993)021<0905:FGATBO >2.3.CO;2.

Bangs, N. L. B., T. H. Shipley, J. C. Moore, and G. F. Moore (1999), Fluid accumulation and channeling along the northern Barbados Ridge decollement thrust, J. Geophys. Res., 104(B9), 20,399-20,414, doi:10.1029/1999JB900133.

Bangs, N. L. B., G. F. Moore, S. P. S. Gulick, E. M. Pangborn, H. J. Tobin, S. Kuramoto, and A. Taira (2009), Broad, weak regions of the Nankai Megathrust and implications for shallow coseismic slip, Earth Planet. Sci. Lett., 284(1-2), 44-49, doi:10.1016/j.epsl.2009.04.026.

Barker, D. H. N., R. Sutherland, S. Henrys, and S. Bannister (2009), Geometry of the Hikurangi subduction thrust and upper plate, North Island, New Zealand, Geochem. Geophys. Geosyst., 10, Q02007, doi:10.1029/2008GC002153.

Barnes, P. M. (1994a), Continental extension of the Pacific Plate at the southern termination of the Hikurangi subduction zone: The North Mernoo Fault Zone, offshore New Zealand, Tectonics, 13(4), 735-754, doi:10.1029/94TC00798.

Barnes, P. M. (1994b), Pliocene-Pleistocene depositional units on the continental slope off central New Zealand: Control by slope currents and global climate cycles, Mar. Geol., 117(1-4), 155-175, doi:10.1016/0025-3227(94)90012-4.

Barnes, P. M., and B. M. Mercier de Lépinay (1997), Rates and mechanics of rapid frontal accretion along the very obliquely convergent southern Hikurangi margin, New Zealand, J. Geophys. Res., 102(B11), 24,931-24,952, doi:10.1029/97JB01384.

Barnes, P. M., B. M. de Lépinay, J. Y. Collot, J. Delteil, and J. C. Audru (1998), Strain partitioning in the transition area between oblique subduction and continental collision, Hikurangi margin, New Zealand, Tectonics, 17(4), 534-557, doi:10.1029/98TC00974.

Barnes, P. M., G. Lamarche, J. Bialas, S. Henrys, I. Pecher, G. L. Netzeband, J. Greinert, J. J. Mountjoy, K. Pedley, and G. Crutchley (2010), Tectonic and geological framework for gas hydrates and cold seeps on the Hikurangi subduction margin, New Zealand, Mar. Geol., 272(1-4), 26-48, doi:10.1016/j.margeo.2009.03.012.

Beavan, J., P. Tregoning, M. Bevis, T. Kato, and C. Meertens (2002), Motion and rigidity of the Pacific Plate and implications for plate boundary deformation, J. Geophys. Res., 107(B10), 2261, doi:10.1029/2001JB000282.

Begg, J. G., and M. R. Johnston (2000), Geology of the Wellington area, 1:250,000 geological map 10, Inst. of Geol. and Nucl. Sci., Lower Hutt, New Zealand.

Berndt, C. (2005), Focused fluid flow in passive continental margins, Philos. Trans. R. Soc. A, 363(1837), 2855-2871.

Borowski, W. S., C. K. Paull, and W. Ussler (1997), Carbon cycling within the upper methanogenic zone of continental rise sediments; An example from the methane-rich sediments overlying the Blake Ridge gas hydrate deposits, Mar. Chem., 57(3-4), 299-311, doi:10.1016/S0304-4203(97)00019-4. 
Brie, A., F. Pampuri, A. Marsala, and O. Meazza (1995), Shear sonic interpretation in gas-bearing sands, paper SPE 30595MS presented at Annual Technical Conference and Exhibition, Soc. of Pet. Eng., Dallas, Tex.

Bruhn, R., W. Parry, and M. Bunds (2000), Tectonics, fluid migration, and fluid pressure in a deformed forearc basin, Cook Inlet, Alaska, Geol. Soc. Am. Bull., 112(4), 550-563, doi:10.1130/0016-7606(2000)112<550:TFMAFP $>2.0$.CO;2.

Bünz, S., and J. Mienert (2004), Acoustic imaging of gas hydrate and free gas at the Storegga Slide, J. Geophys. Res., 109, B04102, doi:10.1029/2003JB002863.

Burwicz, E. B., L. H. Rüpke, and K. Wallmann (2011), Estimation of the global amount of submarine gas hydrates formed via microbial methane formation based on numerical reaction-transport modeling and a novel parameterization of Holocene sedimentation, Geochim. Cosmochim. Acta, 75, 4562-4576, doi:10.1016/j.gca.2011.05.029.

Calahorrano, B. A., V. Sallarès, J. Y. Collot, F. Sage, and C. R. Ranero (2008), Nonlinear variations of the physical properties along the southern Ecuador subduction channel: Results from depth-migrated seismic data, Earth Planet. Sci. Lett., 267(3-4), 453-467, doi:10.1016/j.epsl.2007.11.061.

Claypool, G. E., A. V. Milkov, Y. J. Lee, M. E. Torres, W. S. Borowski, and H. Tomaru (2006), Microbial methane generation and gas transport in shallow sediments of an accretionary complex, southern Hydrate Ridge (ODP Leg 204), offshore Oregon, USA, Proc. Ocean Drill. Program Sci. Results, 204, 1-52.

Cole, J., and K. Lewis (1981), Evolution of the TaupoHikurangi subduction system, Tectonophysics, 72(1-2), 1-21, doi:10.1016/0040-1951(81)90084-6.

Crutchley, G. J., A. R. Gorman, I. A. Pecher, S. Toulmin, and S. A. Henrys (2011), Geological controls on focused fluid flow through the gas hydrate stability zone on the southern Hikurangi Margin of New Zealand, evidenced from multichannel seismic data, Mar. Pet. Geol., 28, 1915-1931, doi:10.1016/j.marpetgeo.2010.12.005

Davey, F. J., M. Hampton, J. Childs, M. A. Fisher, K. Lewis, and J. R. Pettinga (1986), Structure of a growing accretionary prism, Hikurangi margin, New Zealand, Geology, 14(8), 663-666, doi:10.1130/0091-7613(1986)14<663:SOAGAP> 2.0.CO;2

Davy, B., K. Hoernle, and R. Werner (2008), Hikurangi Plateau: Crustal structure, rifted formation, and Gondwana subduction history, Geochem. Geophys. Geosyst., 9, Q07004, doi:10.1029/2007GC001855.

Domenico, S. N. (1974), Effect of water saturation on seismic reflectivity of sand reservoirs encased in shale, Geophysics, 39(6), 759, doi:10.1190/1.1440464.

Domenico, S. N. (1977), Elastic properties of unconsolidated porous sand reservoirs, Geophysics, 42, 1339, doi:10.1190/ 1.1440797.

Duan, Z., N. Møller, and J. H. Weare (1992), An equation of state for the $\mathrm{CH} 4-\mathrm{CO} 2-\mathrm{H} 2 \mathrm{O}$ system: I. Pure systems from 0 to $1000 \mathrm{C}$ and 0 to 8000 bar, Geochim. Cosmochim. Acta, 56(7), 2605-2617, doi:10.1016/0016-7037(92)90347-L.

Erickson, S. N., and R. D. Jarrard (1998), Velocity-porosity relationships for water-saturated siliciclastic sediments, J. Geophys. Res., 103(B12), 30,385-30,406, doi:10.1029/ 98JB02128.

Fiebig, J., A. B. Woodland, W. D'Alessandro, and W. Puettmann (2009), Excess methane in continental hydrothermal emissions is abiogenic, Geology, 37(6), 495, doi:10.1130/G25598A.1.
Field, B. D., et al. (1997), Cretaceous-Cenozoic Geology and Petroleum Systems of the East Coast Region, New Zealand, Inst. Geol. Nucl. Sci. Monogr., vol. 19, Inst. of Geol. and Nucl. Sci., Lower Hutt, New Zealand.

Giggenbach, W. F., M. K. Stewart, Y. Sano, R. L. Goguel, and G. L. Lyon (1995), Isotopic and chemical composition of waters and gases from the East Coast accretionary prism, New Zealand; Isotopic and geochemical techniques applied to geothermal investigations, in Proceedings of the Final Research Co-ordination Meeting On the Application of Isotopic and Geochemical Techniques to Geothermal Exploration in the Middle East, Asia, the Pacific and Africa, IAEATECD 788, pp. 208-231, IAEA, Dumaguete, Philippines.

Gorman, A. R., W. S. Holbrook, M. J. Hornbach, K. L. Hackwith, D. Lizarralde, and I. Pecher (2002), Migration of methane gas through the hydrate stability zone in a low-flux hydrate province, Geology, 30(4), 327-330, doi:10.1130/0091-7613(2002)030<0327:MOMGTT>2.0.CO;2.

Gray, D. (1972), Handbook of American Institute of Physics, McGraw-Hill, New York.

Greinert, J., K. B. Lewis, J. Bialas, I. A. Pecher, A. Rowden, D. A. Bowden, M. De Batist, and P. Linke (2010), Methane seepage along the Hikurangi Margin, New Zealand: Overview of studies in 2006 and 2007 and new evidence from visual, bathymetric and hydroacoustic investigations, Mar. Geol., 272(1-4), 6-25, doi:10.1016/j.margeo.2010.01.017.

Haacke, R. R., G. K. Westbrook, and R. D. Hyndman (2007), Gas hydrate, fluid flow and free gas: Formation of the bottom-simulating reflector, Earth Planet. Sci. Lett., 261(3-4), 407-420, doi:10.1016/j.epsl.2007.07.008.

Haacke, R. R., G. K. Westbrook, and M. S. Riley (2008), Controls on the formation and stability of gas hydraterelated bottom-simulating reflectors (BSRs): A case study from the west Svalbard continental slope, J. Geophys. Res., 113, B05104, doi:10.1029/2007JB005200.

Hayward, N., G. K. Westbrook, and S. Peacock (2003), Seismic velocity, anisotropy, and fluid pressure in the Barbados accretionary wedge from an offset vertical seismic profile with seabed sources, J. Geophys. Res., 108(B11), 2515, doi:10.1029/2001JB001638.

Heimann, M. (2010), How stable is the methane cycle?, Science, 327(5970), 1211, doi:10.1126/science.1187270.

Helgerud, M., J. Dvorkin, A. Nur, A. Sakai, and T. Collett (1999), Elastic-wave velocity in marine sediments with gas hydrates: Effective medium modeling, Geophys. Res. Lett., 26(13), 2021-2024, doi:10.1029/1999GL900421.

Henry, P., S. Lallemant, K. Nakamura, U. Tsunogai, S. Mazzotti, and K. Kobayashi (2002), Surface expression of fluid venting at the toe of the Nankai wedge and implications for flow paths, Mar. Geol., 187(1-2), 119-143, doi:10.1016/S00253227(02)00262-1.

Henrys, S. A., D. J. Woodward, and I. A. Pecher (2009), Variation of bottom-simulating reflection (BSR) strength in a high-flux methane province, Hikurangi margin, New Zealand, in Natural Gas Hydrates - Energy Resource Potential and Associated Geologic Hazards, edited by T. Collett et al., AAPG Mem., 89, 481-489.

Hoffmann, H. J., and T. Reston (1992), Nature of the S reflector beneath the Galicia Banks rifted margin: Preliminary results from prestack depth migration, Geology, 20(12), 1091, doi:10.1130/0091-7613(1992)020<1091:NOTSRB > 2.3.CO;2.

Holbrook, W. S., H. Hoskins, W. T. Wood, R. A. Stephen, and D. Lizarralde (1996), Methane hydrate and free gas on the blake ridge from vertical seismic profiling, Science, 273(5283), 1840-1843, doi:10.1126/science.273.5283.1840. 
Hornbach, M. J., D. M. Saffer, and W. S. Holbrook (2004), Critically pressured free-gas reservoirs below gas-hydrate provinces, Nature, 427(6970), 142-144, doi:10.1038/ nature 02172.

Hyndman, R., G. Moore, and K. Moran (1993), Velocity, porosity, and pore-fluid loss from the Nankai subduction zone accretionary prism, Proc. Ocean Drill. Program Sci. Results, 131, 211-220.

Kopf, A. (1999), Fate of sediment during plate convergence at the Mediterranean Ridge accretionary complex: Volume balance of mud extrusion versus subduction and/or accretion, Geology, 27(1), 87, doi:10.1130/0091-7613(1999)027<0087: FOSDPC $>2.3 . \mathrm{CO} ; 2$.

Kroeger, K. F., R. Di Primio, and B. Horsfield (2011), Atmospheric methane from organic carbon mobilization in sedimentary basins-The sleeping giant?, Earth Sci. Rev., 107(3-4), 423, doi:10.1016/j.earscirev.2011.04.006.

Kvenvolden, K. A. (1988), Methane hydrate-A major reservoir of carbon in the shallow geosphere?, Chem. Geol., 71(1-3), 41-51, doi:10.1016/0009-2541(88)90104-0.

Kvenvolden, K. A. (1993), Gas hydrates-Geological perspective and global change, Rev. Geophys., 31(2), 173-187, doi:10.1029/93RG00268.

Kvenvolden, K. A. (1995), A review of the geochemistry of methane in natural gas hydrate, Org. Geochem., 23(11-12), 997-1008, doi:10.1016/0146-6380(96)00002-2.

Lee, M. W. (2004), Elastic velocities of partially gas-saturated unconsolidated sediments, Mar. Pet. Geol., 21(6), 641-650, doi:10.1016/j.marpetgeo.2003.12.004.

Lewis, K. B. (2009), Quaternary sedimentation on the Hikurangi oblique-subduction and transform margin, New Zealand, in Sedimentation in Oblique-Slip Mobile Zones, edited by P. F. Ballance and H. G. Reading, pp. 171-189, Blackwell, Oxford, U. K., doi:10.1002/9781444303735.ch10.

Lewis, K. B., and H. M. Pantin (2002), Channel-axis, overbank and drift sediment waves in the southern Hikurangi Trough, New Zealand, Mar. Geol., 192(1-3), 123-151, doi:10.1016/ S0025-3227(02)00552-2.

Lewis, K. B., and J. R. Pettinga (1993), The emerging, imbricate frontal wedge of the Hikurangi margin, in South Pacific Sedimentary Basins, vol. 2, Sedimentary Basins of the World, pp. 225-250, Elsevier, Amsterdam.

Lewis, K. B., J. Y. Collot, and S. E. Lallemand (1998), The dammed Hikurangi Trough: A channel-fed trench blocked by subducting seamounts and their wake avalanches (New Zealand-France GeodyNZ Project), Basin Res., 10(4), 441-468, doi:10.1046/j.1365-2117.1998.00080.x.

Liu, X. L., and P. B. Flemings (2007), Dynamic multiphase flow model of hydrate formation in marine sediments, J. Geophys. Res., 112, B03101, doi:10.1029/2005JB004227.

Lorenson, T. D., T. S. Collett, and R. B. Hunter (2011), Gas geochemistry of the Mount Elbert Gas Hydrate Stratigraphic Test Well, Alaska North Slope: Implications for gas hydrate exploration in the Arctic, Mar. Pet. Geol., 28(2), 343-360, doi:10.1016/j.marpetgeo.2010.02.007.

Løseth, H., M. Gading, and L. Wensaas (2009), Hydrocarbon leakage interpreted on seismic data, Mar. Pet. Geol., 26(7), 1304-1319, doi:10.1016/j.marpetgeo.2008.09.008.

Løseth, H., L. Wensaas, B. Arntsen, N. M. Hanken, C. Basire, and K. Graue (2010), $1000 \mathrm{~m}$ long gas blow-out pipes, Mar. Pet. Geol., 28, 1047-1060.

Lu, H., Y. Seo, J. Lee, I. Moudrakovski, J. A. Ripmeester, N. R. Chapman, R. B. Coffin, G. Gardner, and J. Pohlman (2007), Complex gas hydrate from the Cascadia margin, Nature, 445(7125), 303-306, doi:10.1038/nature05463.
MacKay, S., and R. Abma (1992), Imaging and velocity estimation with depth-focusing analysis, Geophys. Wis. Then Tulsa Soc. Explor. Geophys., 57, 1608.

Milkov, A. V. (2010), Worldwide distribution and significance of secondary microbial methane formed during petroleum biodegradation in conventional reservoirs, Org. Geochem., 42, 184-207.

Minshull, T., and R. White (1989), Sediment compaction and fluid migration in the Makran accretionary prism, J. Geophys. Res., 94, 7387-7402, doi:10.1029/JB094iB06p07387.

Moore, J. C., A. Klaus, N. L. Bangs, B. Bekins, C. J. Bücker, W. Brückmann, S. N. Erickson, O. Hansen, T. Horton, and P. Ireland (1998), Consolidation patterns during initiation and evolution of a plate-boundary decollement zone: Northern Barbados accretionary prism, Geology, 26(9), 811-814, doi:10.1130/0091-7613(1998)026<0811:CPDIAE $>2.3 . C O ; 2$.

Moss, J. L., and J. Cartwright (2010), 3D seismic expression of $\mathrm{km}$-scale fluid escape pipes from offshore Namibia, Basin Res., 22, 481-501, doi:10.1111/j.1365-2117.2010.00461.x

Mountjoy, J. J., P. M. Barnes, and J. R. Pettinga (2009), Morphostructure and evolution of submarine canyons across an active margin: Cook Strait sector of the Hikurangi Margin, New Zealand, Mar. Geol., 260(1-4), 45-68, doi:10.1016/ j.margeo.2009.01.006.

Netzeband, G., A. Krabbenhöft, M. Zillmer, C. J. Petersen, C. Papenberg, and J. Bialas (2010), The structures beneath submarine methane seeps: Seismic evidence from Opouawe Bank, Hikurangi Margin, New Zealand, Mar. Geol., 272(1-4), 59-70, doi:10.1016/j.margeo.2009.07.005.

Noguchi, S., N. Shimoda, O. Takano, N. Oikawa, T. Inamori, T. Saeki, and T. Fujii (2011), 3-D internal architecture of methane hydrate-bearing turbidite channels in the eastern Nankai Trough, Japan, Mar. Pet. Geol., 28(10), 1817-1828, doi:10.1016/j.marpetgeo.2011.02.004.

Parker, S. P. (1989), McGraw-Hill dictionary of scientific and technical terms, Appl. Opt., 28, 1849.

Paull, C. K., W. Ussle Iii, and W. S. Borowski (1994), Sources of biogenic methane to form marine gas hydrates in situ production or upward migration?, Ann. N. Y. Acad. Sci., 715(1), 392-409, doi:10.1111/j.1749-6632.1994.tb38852.x.

Pecher, I. A., N. Kukowski, C. Huebscher, J. Greinert, and J. Bialas (2001), The link between bottom-simulating reflections and methane flux into the gas hydrate stability zone-new evidence from Lima Basin, Peru Margin, Earth Planet. Sci. Lett., 185(3-4), 343-354, doi:10.1016/S0012821X(00)00376-9.

Pecher, I. A., S. A. Henrys, W. T. Wood, N. Kukowski, G. J. Crutchley, M. Fohrmann, J. Kilner, K. Senger, A. R. Gorman, and R. B. Coffin (2010), Focussed fluid flow on the Hikurangi Margin, New Zealand-Evidence from possible local upwarping of the base of gas hydrate stability, Mar. Geol., 272(1-4), 99-113, doi:10.1016/j.margeo.2009.10.006.

Plaza-Faverola, A., S. Bünz, and J. Mienert (2010), Fluid distributions inferred from $\mathrm{P}$ wave velocity and reflection seismic amplitude anomalies beneath the Nyegga pockmark field of the mid-Norwegian margin, Mar. Pet. Geol., 27(1), 46-60, doi:10.1016/j.marpetgeo.2009.07.007.

Plaza-Faverola, A., S. Bünz, and J. Mienert (2011), Repeated fluid expulsion through sub-seabed chimneys offshore Norway in response to glacial cycles, Earth Planet. Sci. Lett., 305(3-4), 297-308, doi:10.1016/j.epsl.2011.03.001.

Reyners, M., D. Eberhart-Phillips, and S. Bannister (2011), Tracking repeated subduction of the Hikurangi Plateau beneath New Zealand, Earth Planet. Sci. Lett., 311, 165-171, doi:10.1016/j.epsl.2011.09.011 
Roberts, H. H., and R. S. Carney (1997), Evidence of episodic fluid, gas, and sediment venting on the northern Gulf of Mexico continental slope, Econ. Geol., 92(7-8), 863, doi:10.2113/gsecongeo.92.7-8.863.

Rogers, K. M., J. D. Collen, J. H. Johnston, and N. E. Elgar (1999), A geochemical appraisal of oil seeps from the East Coast Basin, New Zealand, Org. Geochem., 30, 593-605, doi:10.1016/S0146-6380(99)00036-4.

Saffer, D. M., and E. J. Screaton (2003), Fluid flow at the toe of convergent margins: Interpretation of sharp porewater geochemical gradients, Earth Planet. Sci. Lett., 213(3-4), 261-270, doi:10.1016/S0012-821X(03)00343-1.

Saffer, D. M., and H. J. Tobin (2011), Hydrogeology and mechanics of subduction zone forearcs: Fluid flow and pore pressure, Annu. Rev. Earth Planet. Sci., 39, 157-186, doi:10.1146/annurev-earth-040610-133408.

Schoell, M. (1988), Multiple origins of methane in the earth, Chem. Geol., 71(1-3), 1-10, doi:10.1016/0009-2541(88) 90101-5.

Schwalenberg, K., M. Haeckel, J. Poort, and M. Jegen (2010), Evaluation of gas hydrate deposits in an active seep area using marine controlled source electromagnetics: Results from Opouawe Bank, Hikurangi Margin, New Zealand, Mar. Geol., 272(1-4), 79-88, doi:10.1016/j.margeo.2009.07.006.

Screaton, E., D. Saffer, P. Henry, and S. Hunze (2002), Porosity loss within the underthrust sediments of the Nankai accretionary complex: Implications for overpressures, Geology, 30(1), 19-22, doi:10.1130/0091-7613(2002) $030<0019$ :PLWTUS $>2.0$.CO;2.

Serie, C., M. Huuse, and N. H. Schødt (2012), Gas hydrate pingoes: Deep seafloor evidence of focused fluid flow on continental margins, Geology, 40(3), 207, doi:10.1130/G32690.1.

Sloan, E. D., Jr. (1998), Physical/chemical properties of gas hydrates and application to world margin stability and climatic change, Geol. Soc. Spec. Publ., 137(1), 31, doi:10.1144/GSL. SP.1998.137.01.03.

SO-214 Scientific Party (2011), FS SONNE Fahrtbericht/Cruise Report SO214 NEMESYS: 09.03.-05.04. 2011, WellingtonWellington, 06.-22.04. 2011 Wellington-Auckland, IFMGEOMAR Rep. 47, IFM-GEOMAR, Kiel, Germany.

Taylor, M., W. Dillon, and I. Pecher (2000), Trapping and migration of methane associated with the gas hydrate stability zone at the Blake Ridge Diapir: new insights from seismic data, Mar. Geol., 164(1-2), 79-89, doi:10.1016/S0025-3227(99) 00128-0.

Tobin, H. J., and D. M. Saffer (2009), Elevated fluid pressure and extreme mechanical weakness of a plate boundary thrust, Nankai Trough subduction zone, Geology, 37(8), 679-682, doi:10.1130/G25752A.1.

Uruski, C. I. (2010), New Zealand's deepwater frontier, Mar. Pet. Geol., 27(9), 2005-2026, doi:10.1016/j.marpetgeo. 2010.05.010.

Vanneste, M., M. De Batist, A. Golmshtok, A. Kremlev, and W. Versteeg (2001), Multi-frequency seismic study of gas hydrate-bearing sediments in Lake Baikal, Siberia, Mar. Geol., 172(1-2), 1-21, doi:10.1016/S0025-3227(00)00117-1.

Vannucchi, P., F. Sage, J. P. Morgan, F. Remitti, and J. Y. Collot (2012), Toward a dynamic concept of the subduction channel at erosive convergent margins with implications for interplate material transfer, Geochem. Geophys. Geosyst., 13, Q02003, doi:10.1029/2011GC003846.

Wallace, L. M., P. Barnes, J. Beavan, R. Van Dissen, N. Litchfield, J. Mountjoy, R. Langridge, G. Lamarche, and N. Pondard (2012), The kinematics of a transition from subduction to strike-slip: An example from the central New Zealand plate boundary, J. Geophys. Res., 117, B02405, doi:10.1029/2011JB008640.

Wallmann, K., G. Aloisi, M. Haeckel, A. Obzhirov, G. Pavlova, and P. Tishchenko (2006), Kinetics of organic matter degradation, microbial methane generation, and gas hydrate formation in anoxic marine sediments, Geochim. Cosmochim. Acta, 70(15), 3905-3927, doi:10.1016/j.gca.2006.06.003.

Westbrook, G. (1991), Geophysical evidence for the role of fluids in accretionary wedge tectonics, Philos. Trans. R. Soc. A, 335(1638), 227-242, doi:10.1098/rsta.1991.0044.

Wiese, K., and K. A. Kvenvolden (1993), Introduction to microbial and thermal methane, U.S. Geol. Surv. Prof. Pap., $1570,13-20$.

Wood, R., and B. Davy (1994), The Hikurangi Plateau, Mar. Geol., 118(1-2), 153-173, doi:10.1016/0025-3227(94) 90118-X. 